\title{
軸力制限機構付き同調粘性マスダンパーの実大加振実験とその解析的検証 FULL-SCALE DYNAMIC TESTS OF TUNED VISCOUS MASS DAMPER WITH FORCE RESTRICTION MECHANISM AND ITS ANALYTICAL VERIFICATION
}

\author{
木田英範*1, 渡邊義仁*2, 中南滋樹*3, 田中久也*4 \\ 杉村義文*5, 斉藤賢二*6, 五十子幸樹*7, 井上範夫*8 \\ Hidenori KIDA, Yoshihito WATANABE, Shigeki NAKAMINAMI, \\ Hisaya TANAKA, Yoshifumi SUGIMURA, Kenji SAITO, \\ Kohju IKAGO and Norio INOUE
}

\begin{abstract}
The authors have proposed the tuned viscous mass damper system based on the fixed points theory, and have proved the validity of the theory and the analysis method through the vibration tests of the small scale test specimen. The testing program revealed that an increase in equivalent inertial mass of viscous mass damper and increase in input resulted in an excessive stresses in the supporting member, damper body and the primary structure connected to the damper. In this paper, authors built the rotation slipping mechanism into the main body of the full-scale tuned viscous mass damper with the spring member of $18,200 \mathrm{kN} / \mathrm{m}$ and the equivalent inertial mass of 1,350 ton, and tested the tuned viscous mass damper with the force restriction mechanism. Analysis parameters of the tuned viscous mass damper with the force restriction mechanism were evaluated accurately and the test results corresponded well with the analytical results. From the analysis results for a 1-story structure, it is shown that this restriction mechanism can effectively reduce the damper maximum force and the maximum response displacement is almost the same as the result obtained by a restriction-free damper.
\end{abstract}

\section{Keywords : Passive Control, Rotative Inertia, Tuned Viscous Mass Damper, Full-Scale Dynamic Tests, Damper force Restriction Mechanism パッシブ制振，回転慣性，同調粘性マスダンパー，実大加振実験，軸力制限機構}

1.はじめに

近年、著者らはこれまでに図 1 に示すような節点間の加速度差に 比例して抵抗力を生じる回転慣性を利用した慣性接続要素と粘性減 衰要素を併せ持つ粘性マスダンパーに、柔支持部材を直列に接続し て構成される付加的な振動系（同調粘性マスダンパー）を用いた新 たな制振システムの応答制御法 ${ }^{1) ~ 99}$ について解析的・実験的な検討 を行っている。同調粘性マスダンパーの固有振動数と主系の固有振 動数を適切に同調させることにより、粘性要素の相対変位が動的に 拡大寸るため、支持部材要素と粘性要素のみでは得られなかった大 きな振動エネルギー吸収効果を得ることができる。このため、図 2 に示すような絶対加速度に比例して抵抗力を生じる実質量を利用し た動吸振器つまり TMD（Tuned Mass Damper）における応答制御法

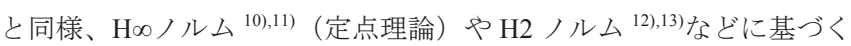
設計法を用いれば、比較的小さな質量比（付加系の慣性接続要素の 等価質量を主系の主質量で除したもの）と比較的小さな粘性減衰係 数および支持部材剛性の組み合わせでも、効果的に主系の共振点近

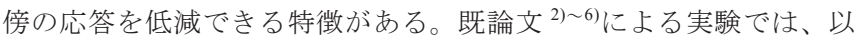
上のような同調粘性マスダンパーを有する Hoノルムを利用した一
層応答制御システム（変位応答倍率最適調整条件）の縮小試験体の 振動実験や、等価質量 1,450ton を有する同調粘性マスダンパーつま り付加振動系としての実大要素加振実験を行い、その制振効果につ いて理論および解析手法の妥当性を実証している。しかしながらこ れらの実験では、粘性マスダンパーの等価質量等の増大や想定外の 入力により、支持部材および粘性マスダンパー本体や、これに接続 される主系の構造体に過大な応力を生じさせるものであった。過大 な軸力を制限する機構として、回転滑り機構を用いることを提案す
相対加速度 $\ddot{u}_{d}$ により慣性力 $m \cdot \ddot{u}_{d}$ を発揮する慣性接続要素の等価質 量 (回転慣性) を使用

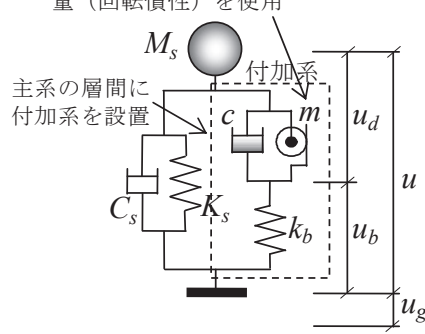

図 1 同調粘性マスダンパー

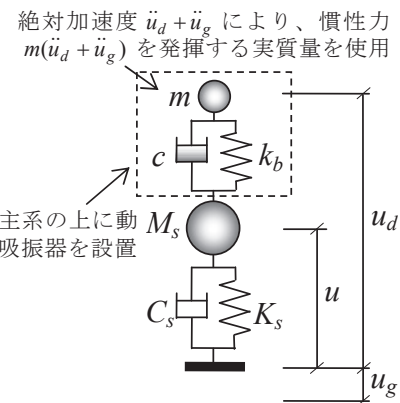

図 2 実質量を利用した動吸振器
Structural Design Department, Aseismic Devices, CO., LTD., Dr. Eng.

Amenity Creation Engineering Division, THK CO., LTD.

Technical Department, Aseismic Devices, CO., LTD., M. Eng.

Technical Department, Aseismic Devices, CO., LTD.

Research and Development Headquarters, NTT Facilities, INC., M. Eng. Design Headquarters, NTT Facilities, INC., Dr. Eng.

Assoc. Prof., Graduate School of Engineering, Tohoku University, Dr. Eng.

Prof., Graduate School of Engineering, Tohoku University, Dr. Eng. 
るが、同様のことは磯田ら ${ }^{14)}$ も提案している。本論文で提案する軸 力制限機構付き粘性マスダンパーは、磯田らの提案する回転滑り機 構（クラッチ機構やディスクブレーキ機構）を組み込む点では同じ だが、速度に依存する粘性減衰力と加速度に依存する慣性力のそれ ぞれ位相が異なる力を足し合わせた合力を頭打ちにできる点で大き く異なる機構となっている。文献 ${ }^{9), 14)}$ では、これらのダンパー軸力 制限機構を適用した場合の制振効果の利点（ダンパー最大軸力を抑 えつつ効果的に主系の最大応答值を低減できる）が論じられている。

本論文では、実大サイズでの軸力制限機構付き同調粘性マスダン パー（等価質量 $1,350 \mathrm{ton} 、$ 支持部材 $18,200 \mathrm{kN} / \mathrm{m}$ ) の実大要素加振実 験（主系の層間変位をモデル化したアクチュエータの変位入力によ る加振）により、理論および解析手法の妥当性の検証を行うととも に、軸力制限機構付き同調粘性マスダンパーを主系の構造体に組み 込み、軸力制限機構の有無や制限荷重の違いによる地震応答解析を 行うことで、軸力制限機構を適用した場合の制振効果の利点につい て検討を行うことを目的としている。以降、本論文では、支持部材 を含めた軸力制限機構付き同調粘性マスダンパーを Force-Restricted Tuned Viscous Mass Damper（FRTVMD）と呼ぶ。

\section{2. 試験体とモデル化}

\section{1 試験体概要}

載荷装置の全景および FRTVMD の実大試験体（軸力制限機構付き 粘性マスダンパー十支持部材）を図 3 と写真 1 に示す。加振は、最 大荷重 $\pm 3,000 \mathrm{kN}$ 、最大振幅 $\pm 100 \mathrm{~mm}$ 、最大速度 $\pm 300 \mathrm{~mm} / \mathrm{s}$ の性能を 有するダイナミックアクチュエータを用い、正弦波や地震応答波に よる入力を行った。变位の測定は、試験フレーム上部梁の回転角の 影響を含んだ支持部材部、軸力制限機構付き粘性マスダンパー部、 これらをすべて足し合わせた FRTVMD 部（うアクチュエータの入 力変位）それぞれについて行い、荷重はアクチュエータ先端のロー ドセルにより測定した。ロードセルの荷重はアクチュエータに取り 付く加振テーブルの摩擦力 $3 \mathrm{kN}$ が加算されるため、図 6 以降の実験 結果は、この摩擦力 $3 \mathrm{kN}$ を減じる処理を行っている。

\section{2 軸力制限機構付き粘性マスダンパーの概要と解析モデル}

図 4 に、慣性接続要素と粘性要素を併せ持つ軸力制限機構付き粘 性マスダンパーの機構模式図を示す。本装置に入力される直線運動

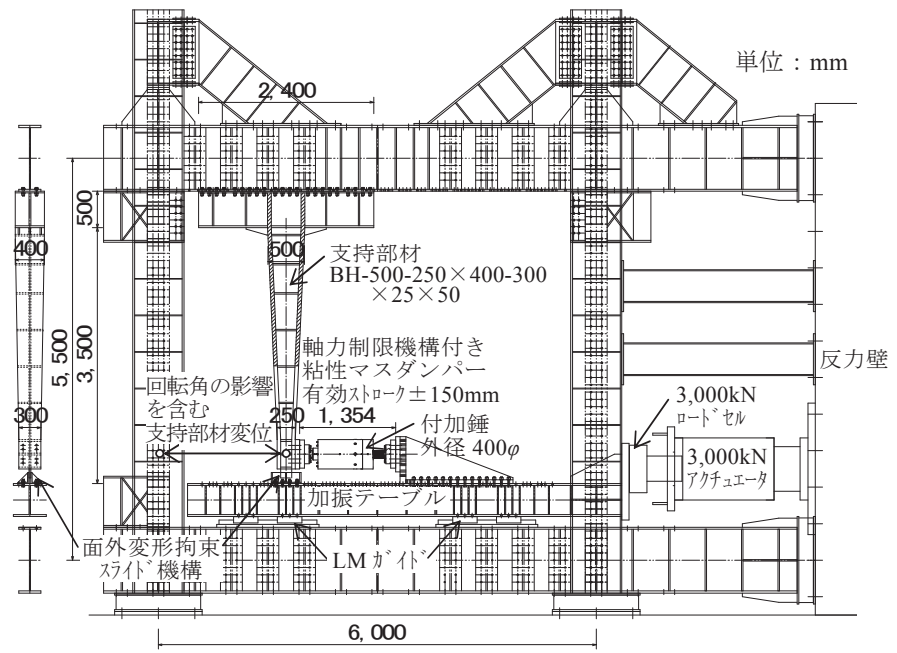

図 3 FRTVMD 実大試験体の全景
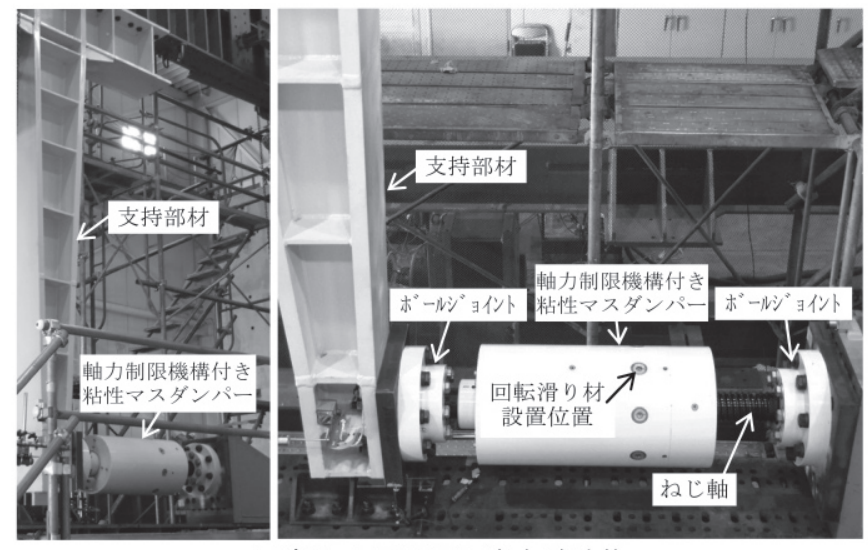

写真 1 FRTVMD 実大試験体

を、ボールねじによりボールナットおよび付加錘の回転運動に増幅 変換し、固定された内筒と付加錘の間に充填された粘性体のせん断 抵抗により粘性減衰効果を、さらにボールナットおよび付加錘の質 量が回転することにより回転慣性質量効果を得ることができる装置 である。ボールナットと付加錘の連結部に回転滑り機構を設けるこ とにより、付加錘十粘性体による伝達トルクを頭打ちにする機構と なっている。計 8 籄所に設置した回転滑り材（材質 : 超高分子量ポ リエチレン、摩擦係数 $\mu_{f}=0.15$ 程度）は、ボルトの締め付けにより皿. バネを介して回転滑り材に軸力を与える機構となっており、その軸 力を自在に管理することで、回転滑りによるトルクを自在にコント ロールすることができる。

以下、 $u_{d}$ および $\theta$ は軸力制限機構付き粘性マスダンパーに入力さ れる軸方向変位とそれに伴う角変位を、 $\theta_{f}$ および $u_{d f}$ は回転滑りによ る角変位とそれに伴う見かけの軸方向変位を、 $\theta_{d}$ および $u_{d d}$ は付加錘 の回転による角変位とそれに伴う見かけの軸方向変位を示す。回転 滑りが生じない場合は $\theta_{f}=u_{d f}=0$ である。軸方向と回転方向の関係式 (1リード長 $L_{d}$ で 1 回転つまり $\left.2 \pi\right)$ より、次式が成立する。

$$
\begin{aligned}
& u_{d}=u_{d f}+u_{d d}, \quad \theta=\theta_{f}+\theta_{d} \\
& u_{d}=\frac{L_{d}}{2 \pi} \cdot \theta, \quad u_{d f}=\frac{L_{d}}{2 \pi} \cdot \theta_{f}, \quad u_{d d}=\frac{L_{d}}{2 \pi} \cdot \theta_{d} \\
& \text { ボールットと一緒に回転 } \\
& \text { クロスローラーベアリングリ緒に回転 } \\
& \text { ねじ軸ボール外回転滑り材 }
\end{aligned}
$$

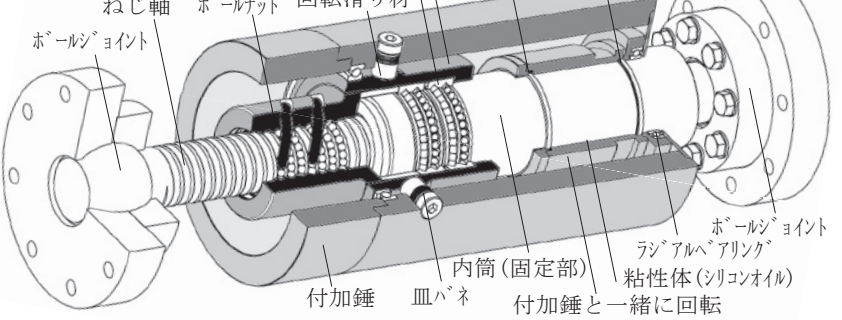

色付け部：回転体を示寸

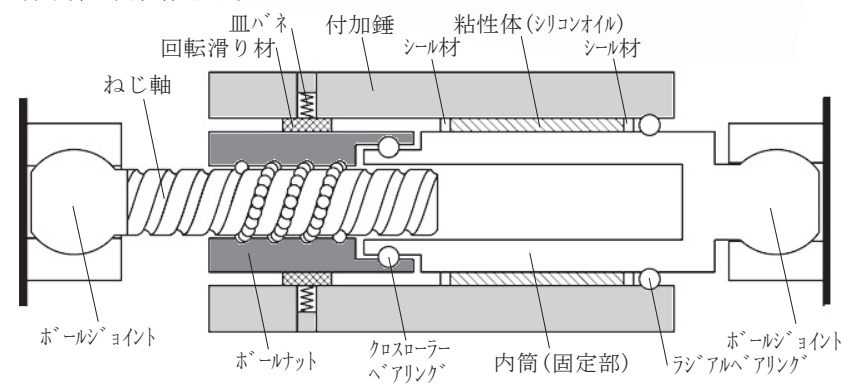

図 4 軸力制限機構付き粘性マスダンパーの機構模式図 
図 4 の両端部に設置されているボールジョイントは、付録 $\mathrm{A}$ に示 す式(A19)の条件を満たすため、軸力制限機構付き粘性マスダンパー の発生するトルクでは回転しない機構となっている。この装置の最 終的な解析モデルを式(2)と図 5 に示す。ここで、ボールナット部の 等価質量 $m_{i 0}$ が、付加鍾部の等価質量 $m_{i 1}$ より十分に小さい（ダンパ 一抵抗力 $P_{n}$ に与える影響が十分に小さい）とき、ボールナット部の 等価質量 $m_{i 0}$ のモデル化については省略できる。

回転滑りなし：

$$
\begin{aligned}
& u_{d f}=0, u_{d}=u_{d d},\left|c_{d}\left(\dot{u}_{d d}\right) \cdot \dot{u}_{d d}+m_{i 1} \cdot \ddot{u}_{d d}\right|<\left|F_{r}\right| \\
& P_{n}=c_{d}\left(\dot{u}_{d d}\right) \cdot \dot{u}_{d d}+m_{i 1} \cdot \ddot{u}_{d d}=c_{d}\left(\dot{u}_{d}\right) \cdot \dot{u}_{d}+m_{i 1} \cdot \ddot{u}_{d}
\end{aligned}
$$

回転滑りあり：

$u_{d}=u_{d f}+u_{d d}, c_{d}\left(\dot{u}_{d d}\right) \cdot \dot{u}_{d d}+m_{i 1} \cdot \ddot{u}_{d d}=F_{r}$

$P_{n}=F_{r}$

ここで、 $c_{d}\left(\dot{u}_{d d}\right)=c_{v}\left(\dot{u}_{d d}\right)+c_{f}\left(\dot{u}_{d d}\right)$

$\left\{\begin{array}{l}P_{n}: \text { 軸力制限機構付き粘性マスダンパーの軸方向全抵抗力 } \\ F_{r}: \text { 回転滑り機構による摩擦抵抗トルクを軸方向力にモデル化 } \\ c_{v}\left(\dot{u}_{d d}\right): \text { 粘性体によるせん断抵抗を軸方向にモデル化 } \\ c_{f}\left(\dot{u}_{d d}\right): \text { シール材などによる摩擦抵抗を軸方向にモデル化 }\end{array}\right.$

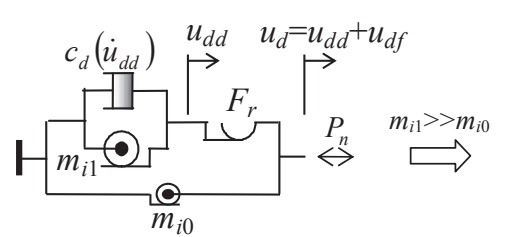

装置剛性は支持部材剛性に比心゙ 十分に剛である。 $c_{d}\left(\dot{u}_{d d}\right) \stackrel{u_{d d}}{\longmapsto}$

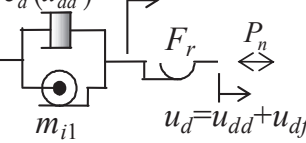

図 5 軸力制限機構付き粘性マスダンパーの解析モデル

式(2)は、摩擦抵抗や粘性抵抗力、回転慣性による慣性力および回 転滑りによる制限荷重などの成分を粘性減衰係数 $c_{d}\left(\dot{u}_{d d}\right)$ と等価質量 $m_{i 1}$ と制限荷重 $F_{r}$ で表したモデルである。この 3 つの係数を実験に より正確に評価することで、実用上精度良く軸力制限機構付き粘性 マスダンパーの性能を把握することができる。式(2)のモデルの設定 根拠については付録 A に示寸。回転滑り機構で滑らない場合には文 献ので示す通りである。本実験で使用する軸力制限機構付き粘性マ スダンパーの主要な寸法を表 1 に示す。

\begin{tabular}{|c|c|c|c|}
\hline 項 & 記 号 & 単 位 & 数 值 \\
\hline ねじ軸半径 & $r_{S S}$ & $\mathrm{~mm}$ & 50.0 \\
\hline リード長 & $L_{d}$ & $\mathrm{~mm}$ & 20.0 \\
\hline クロスローラーベアリング半径 & $r_{C B}$ & $\mathrm{~mm}$ & 88.7 \\
\hline 粘性体のせん断抵抗半径 & $r_{v}$ & $\mathrm{~mm}$ & 85.0 \\
\hline 粘性体の接している長さ & $L_{s}$ & $\mathrm{~mm}$ & 165.0 \\
\hline せん断隙間 & $d y$ & $\mathrm{~mm}$ & 2.0 \\
\hline シール材半径 & $r_{s i}$ & $\mathrm{~mm}$ & 85.0 \\
\hline ラジアルベアリング半径 & $r_{R B}$ & $\mathrm{~mm}$ & 85.0 \\
\hline 付加錘外径 & $2 r_{o 1}$ & $\mathrm{~mm}$ & 400.0 \\
\hline
\end{tabular}

表 1 軸力制限機構付き粘性マスダンパーの主要な寸法一覧

\section{3 軸力制限機構付き粘性マスダンパー諸元の算定}

式(2)でモデル化される粘性減衰係数 $c_{d}\left(\dot{u}_{d d}\right)$ および等価質量 $m_{i 1}$ の回 転滑りが生じない状態での諸元を評価するにあたっては、製造ばら つきの影響を評価できない設計諸元から算出するのでなく、正弦波 加振実験を行いその結果から算出を行った。図 6 に、回転滑りが生 じない状態での軸力制限機構付き粘性マスダンパーに入力された変
位と荷重の関係（前後テーパー付き正弦波加振実験結果）を示す。

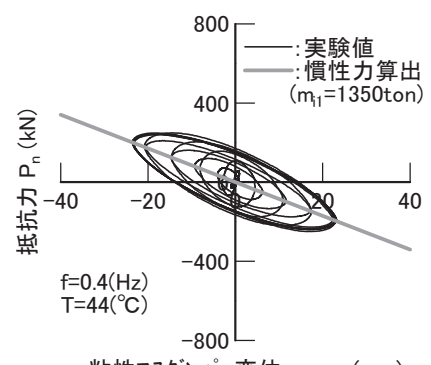

粘性マスダンパー変位 $\mathrm{u}_{\mathrm{d}}=\mathrm{u}_{\mathrm{dd}}(\mathrm{mm})$

(a) 振動数 $0.4 \mathrm{~Hz}$ 正弦波加振時

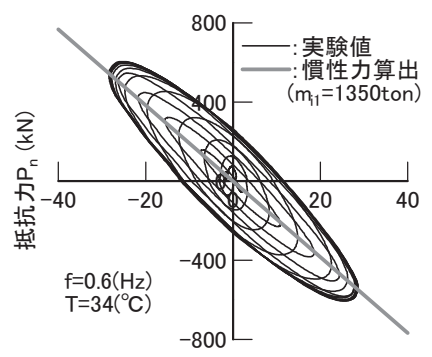

粘性マスダンパー変位 $\mathrm{u}_{\mathrm{d}}=\mathrm{u}_{\mathrm{dd}}(\mathrm{mm})$

(b) 振動数 $0.6 \mathrm{~Hz}$ 正弦波加振時
図 6 粘性マスダンパーの装置に入力された変位と荷重の関係

図 6 の実験結果より、変位と荷重関係の履歴形状は右肩下がりと なるが、変位を $u_{d}=\delta \sin p t （ p$ は加振円振動数）とすると、速度は $\dot{u}_{d}=p \delta \cos p t$ 、加速度は $\ddot{u}_{d}=-p^{2} \delta \sin p t$ と表されるため、最大変位 $\delta$ となる時刻の時は、速度が 0 、加速度が $-p^{2} \delta$ （マイナスの最大加 速度）となり、慣性力 $-m_{i 1} p^{2} \delta$ のみ生じるため、右肩下がりの履歴 形状を示している。この結果から等価質量を算出すると $m_{i 1}=1,350$ ton であった。回転体の実質量は 0.435 ton であるため、3100 倍程度の質 量増幅率を有する装置となっている。

図 7 に、微小速度領域における軸力制限機構付き粘性マスダンパ 一の装置に入力された変位と荷重 $P_{n}$ の関係を示し、図 8 に、軸力制 限機構付き粘性マスダンパーの装置に入力された速度と式(2)に示寸 粘性減衰力 $c_{d}\left(\dot{u}_{d d}\right) \cdot \dot{u}_{d d}$ の関係を示寸。図 8 の実験值 (○印) は、図 6 の慣性力の影響がない切片での速度一荷重関係を示したものである。

(図 7,8 は、回転滑りが生じない状態での前後テーパー付き正弦波 加振実験結果である。）

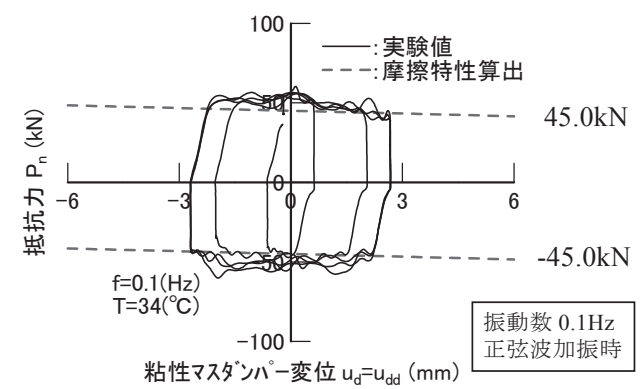

図 7 粘性マスダンパーの変位と荷重の関係（微小速度領域）

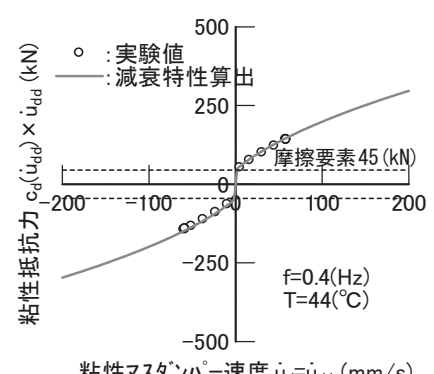

粘性マスダンパー速度 $\dot{u}_{\mathrm{d}}=\dot{\mathrm{u}}_{\mathrm{dd}}(\mathrm{mm} / \mathrm{s})$

(a) 振動数 $0.4 \mathrm{~Hz}$ 正弦波加振時

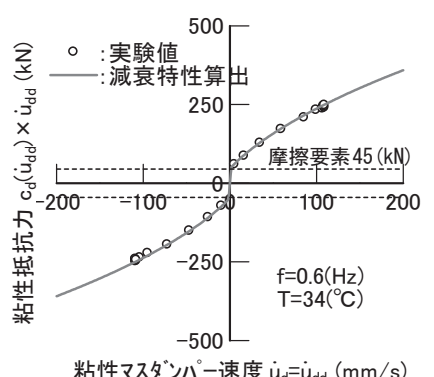

粘性マスダンパー速度 $\dot{u}_{d}=\dot{u}_{d d}(\mathrm{~mm} / \mathrm{s})$ (b) 振動数 $0.6 \mathrm{~Hz}$ 正弦波加振時
図 8 粘性マスダンパーに入力された速度と粘性減衰力の関係

図 7 の実験結果より、式(2)中の摩擦要素 $c_{f}\left(\dot{u}_{d d}\right) \cdot \dot{u}_{d d}$ は $45.0 \mathrm{kN}$ 程 度であったため、式(3)のように表される。 
$\left\{\begin{array}{l}\left|\dot{u}_{d d}\right|<\varepsilon \text { のとき、 } c_{f}\left(\dot{u}_{d d}\right) \cdot \dot{u}_{d d}=\frac{45.0}{\varepsilon} \times \dot{u}_{d d}(\mathrm{kN}) \\ \left|\dot{u}_{d d}\right| \geq \varepsilon \text { のとき、 } c_{f}\left(\dot{u}_{d d}\right) \cdot \dot{u}_{d d}=\operatorname{sgn}\left(\dot{u}_{d d}\right) \times 45.0(\mathrm{kN}) \\ \text { こで、 } \varepsilon=1.7 \mathrm{~mm} / \mathrm{s} \text { (図7 の最大速度) として解析を行う。 }\end{array}\right.$

式(2)中の粘性要素 $c_{v}\left(\dot{u}_{d d}\right) \cdot \dot{u}_{d d}$ は、図 8 に示寸実験值と付録 $\mathrm{A}$ の式 (A7), (A23)の関数を利用し、式(4)のような実験近似式を算出した。 $c_{v}\left(\dot{u}_{d d}\right) \cdot \dot{u}_{d d}=\frac{5943.4 \times 1.02^{(39-T)}}{2000.0+94.7 \times\left|\dot{u}_{d d}\right|^{0.6}} \cdot \dot{u}_{d d}, \quad \begin{gathered}\dot{u}_{d d} \text { の単位 }: \mathrm{mm} / \mathrm{s} \\ 34^{\circ} \mathrm{C} \leq \text { 温度 } T \leq 44^{\circ} \mathrm{C}\end{gathered}$

式(4)は、粘性体温度が $34^{\circ} \mathrm{C}$ から $44^{\circ} \mathrm{C}$ までの正弦波加振実験結果よ り算出した近似式であるため、式(4)の適用温度範囲は $34^{\circ} \mathrm{C} ら 54{ }^{\circ} \mathrm{C}$ である。したがって、地震応答波などの加振実験に対しても、式(4) に示寸粘性体の適用温度範囲内で実験を行った。夏場（外気温 $30^{\circ} \mathrm{C}$ 以上）の連続加振による実験のため、やむを得ずこのような温度範 囲となってしまったが、この点は今後の課題である。図 6 の実験結 果より、繰り返し定常加振（前後テーパーを除く）における減衰性 能の低下は見られないため、加振中の温度上昇が本論文での実験と 同等であれば、温度 $T$ を一定として扱っても問題ない範囲であると 言えるが、温度上昇が大幅に大きくなる場合はこの限りではない。

\section{4 支持部材の概要と剛性の算定}

図 3 に、本実験で使用する支持部材の概要を示す。支持部材は八 ンチ形状の BH-500-250 × 400-300 × 25×50 を使用し、支持部材の変 形（モーメント荷重）により応力度が大きくなるフランジ部を降伏 点強度 $\sigma_{y}=450 \mathrm{MPa}$ 、破断強度 $\tau_{s}=590 \mathrm{MPa}$ 相当の高強度鋼材で構成し その他の部位であるウェブや補強リブは SM490 とすることで、粘性 マスダンパーの抵抗力 $1200 \mathrm{kN}$ 程度まで弾性を確保した。支持部材剛 性は、試験フレーム上部梁の回転角による影響を含んで算出する必 要があるため、正弦波加振実験における回転角の影響を含む支持部 材変形と荷重の関係より、支持部材剛性の算出を行うものとする。

(ちなみに、試験フレーム上部梁の回転角の影響を含まない場合の 支持部材剛性の FEM 解析による結果は $23,000 \mathrm{kN} / \mathrm{m}$ 程度である。）

図 9 に、試験フレーム上部梁の回転角の影響を含んだ支持部材の変 位と荷重の関係（前後テーパー付き正弦波加振実験結果）を示寸。

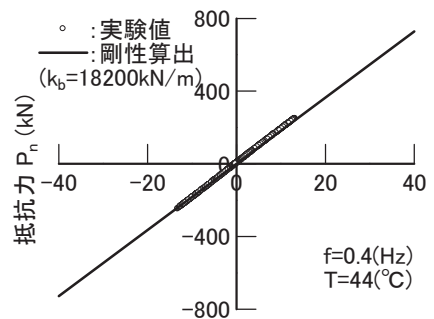

支持部材変位 $u_{b}(\mathrm{~mm})$

(a) 振動数 $0.4 \mathrm{~Hz}$ 正弦波加振時

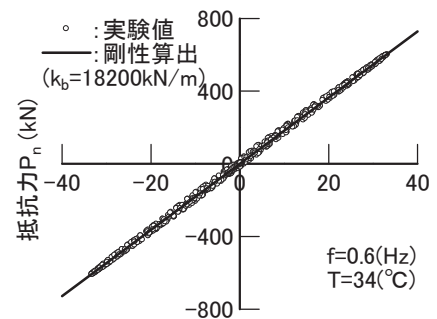

支持部材変位 $u_{b}(\mathrm{~mm})$

(b) 振動数 $0.6 \mathrm{~Hz}$ 正弦波加振時
れた変位と荷重の関係
図 9 の実験結果（試験フレーム上部梁の回転角の影響を含んだ支 持部材の変位と荷重の関係）から最小二乗法で算出した支持部材剛 性は、 $k_{b}=18,200 \mathrm{kN} / \mathrm{m}$ であった。

\section{5 F R T VMDの解析モデル}

FRTVMD は、前節までに論じた回転滑りを利用した軸力制限機構 付き粘性マスダンパー（図 10(a)）と支持部材（図 10(b)）を直列に 組み合わせたものであり、回転すべりが生じない状態では、等価質

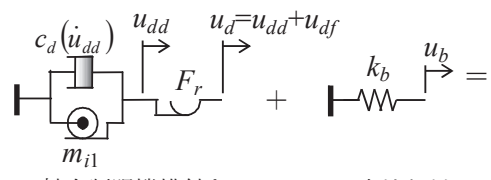

(a) 軸力制限機構付き 粘性マスダンパー

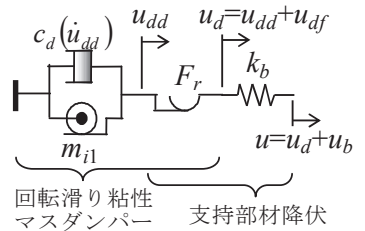

図 10 FRTVMD の構成要素

量 $m_{i 1}$ と支持部材剛性 $k_{b}$ から算出される固有円振動数 $\omega$ を有する機 構である。ここで摩擦要素（制限荷重 $F_{r}$ ） と粘性マスダンパーとの 組み合わせは、軸力制限機構付き粘性マスダンパーを表しているが、 摩擦要素（制限荷重 $F_{r}$ ) と弾性の支持部材とを組み合わせることに よって、支持部材を降伏させたモデルで表現できることがわかる。

支持部材の降伏による方法は、地震終了後の残留変位が問題とな るが、回転滑りによる方法は、回転滑りの角変位 $\theta_{f}$ による見かけの 軸変形 $u_{d f}$ と付加錘の角変位 $\theta_{d}$ による見かけの軸変形 $u_{d d}$ に残留変形 を生じる可能性はあるが、それらを足し合わせた軸力制限機構付き 粘性マスダンパーの軸変形 $u_{d}=u_{d f}+u_{d d} （$ 称じ軸の入力変形）と弾性の 支持部材 $u_{b}$ には残留変形を全く起こさない特徵がある。

図 10 に示寸 FRTVMD 全体に入力される変位（うアクチュエータ の入力変位） $u=u_{d}+u_{b}$ を受けるときの運動方程式は次式で示される。

回転滑りなし：

$$
\begin{aligned}
& u_{d f}=0, u_{d}=u_{d d},\left|c_{d}\left(\dot{u}_{d d}\right) \cdot \dot{u}_{d d}+m_{i 1} \cdot \ddot{u}_{d d}\right|<\left|F_{r}\right| \\
& P_{n}=c_{d}\left(\dot{u}_{d}\right) \cdot \dot{u}_{d}+m_{i 1} \cdot \ddot{u}_{d}=k_{b}\left(u-u_{d}\right)
\end{aligned}
$$

回転滑りあり：

$$
\begin{aligned}
& u_{d}=u_{d f}+u_{d d}, \quad c_{d}\left(\dot{u}_{d d}\right) \cdot \dot{u}_{d d}+m_{i 1} \cdot \ddot{u}_{d d}=F_{r} \\
& P_{n}=F_{r}=k_{b}\left(u-u_{d}\right)
\end{aligned}
$$

回転滑りがない場合の粘性マスダンパーと支持部材の層間変形をモ デル化したアクチュエータの入力変位（定常）に対する変位伝達関 数 (変位応答倍率と位相) は、付加振動系の等価減衰定数 $c_{d}\left(\dot{u}_{d}\right) / m_{i 1}$ $=2 h_{e} \omega$ と固有円振動数 $\omega^{2}=k_{b} / m_{i 1}$ で表現すると次式 ${ }^{6)}$ となる。

$$
\begin{aligned}
& \frac{u_{d}}{u}=\frac{1}{\sqrt{\left\{1-(p / \omega)^{2}\right\}^{2}+\left\{2 h_{e}(p / \omega)\right\}^{2}}} \times e^{-i \psi_{1}} \\
& \frac{u_{b}}{u}=\sqrt{\frac{(p / \omega)^{4}+\left\{2 h_{e}(p / \omega)\right\}^{2}}{\left\{1-(p / \omega)^{2}\right\}^{2}+\left\{2 h_{e}(p / \omega)\right\}^{2}}} \times e^{-i\left(\psi_{1}-\psi_{2}\right)}
\end{aligned}
$$

$\psi_{1}=\tan ^{-1} \frac{2 h_{e}(p / \omega)}{1-(p / \omega)^{2}}, \quad \psi_{2}=\tan ^{-1} \frac{2 h_{e}(p / \omega)}{-(p / \omega)^{2}}, \quad p:$ 加振円振動数

本実験では回転すべりが生じない場合、等価質量 $m_{i 1}=1,350$ ton、支 持部材剛性 $k_{b}=18,200 \mathrm{kN} / \mathrm{m}$ であるので、FRTVMD（付加振動系）の 固有円振動数 $\omega=3.67 \mathrm{rad} / \mathrm{s}$ となる。また制限荷重 $F_{r}\left(\dot{u}_{d f}\right.$ と同符号 $)$ は、回転滑り材に与える軸力を調整することで約 $800 \mathrm{kN}$ と約 $400 \mathrm{kN}$ の 2 種類に設定し実験を行った。

\section{3. 正弦波加振による検証}

本章では正弦波加振を行って、FRTVMD の基本的応答性状を明ら 
かにし、その解析モデルの精度と制振効果を検討する。正弦波加振 はFRTVMD 全体（うアクチュエータの入力）の変位制御とした。 本装置の機構上、熱電対により粘性体の温度を直接測定することが できなかったが、長時間加振（トータル正弦波を 20 波）に対しても 粘性体に接する鋼材の熱容量は粘性体の熱容量 $0.062 \mathrm{kcal} /{ }^{\circ} \mathrm{C}$ の約 150 倍と十分大きく、またボールねじ部やクロスローラーベアリング部 の摩擦によるエネルギー負担分が軽減されるため、粘性体に直接接 する鋼材の温度上昇は $3^{\circ} \mathrm{C}$ 程度以内におさまっており、減衰性能に 与える影響はほとんどないことを確認している。

制限荷重 $F_{r}=$ 約 $800 \mathrm{kN}$ に設定した場合（回転滑りを生じさせない 場合）における振幅 $15 \mathrm{~mm}$ の振動数 $0.4,0.55,0.6 \mathrm{~Hz}$ の正弦波加振結 果（定常部分：18s から 23s）を図 11,12,13に、図 14 に式(6),(7)で示 寸入力変位に対する粘性マスダンパーおよび支持部材の変位応答倍 率と位相曲線を示寸。図 14 中には、 $h_{e}=0.2,0.25,0.3$ を式(6),(7)に代 入した場合の解析值と正弦波加振結果より得られた実験值 を示しており、その中で○印で囲んだものは図 11,12,13に示したも のである。また、図 11,12,13 中の変位の時刻歴波形は実験值を示し、 履歴中の解析值 (破線) は、減衰係数 $c_{d}\left(\dot{u}_{d d}\right)$ の非線形性を考慮して 時刻歴解析により算定を行った結果を示している。

図 11〜14より、軸力制限機構付き粘性マスダンパー変位 $u_{d}$ と支持 部材変位 $u_{b}$ は、FRTVMD（付加振動系）の固有円振動数付近の加振 においては同調するため逆位相で変形し、入力変位に対してそれら の変位（粘性マスダンパーの使用速度領域）が拡大寸る。その結果、

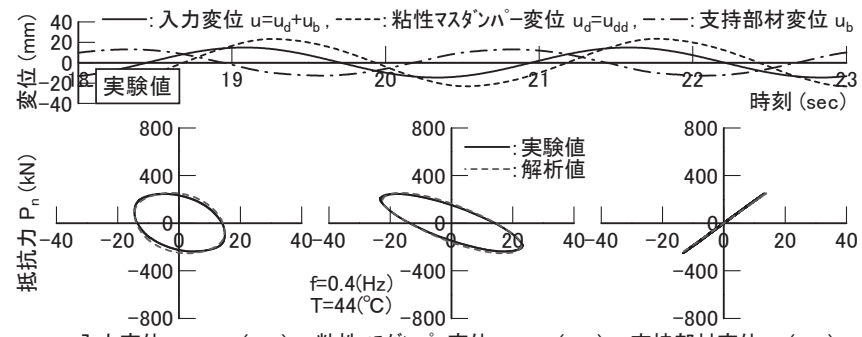

入力変位 $u=u_{d}+u_{b}(m m) \quad$ 粘性又スダンパ-変位 $u_{d}=u_{d d}(m m) \quad$ 支持部材変位 $u_{b}(m m)$

図 $11 F_{r}=$ 約 $800 \mathrm{kN}$ 、振幅 $15 \mathrm{~mm}$ 、振動数 $0.4 \mathrm{~Hz}$ 正弦波加振結果

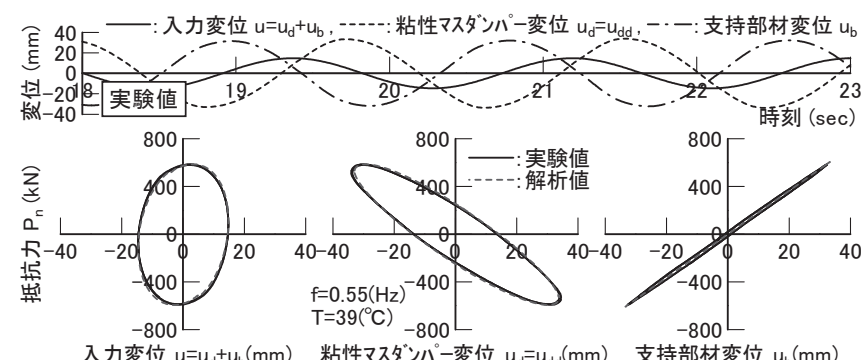
図 $12 F_{r}=$ 約 $800 \mathrm{kN}$ 、振幅 $15 \mathrm{~mm}$ 、振動数 $0.55 \mathrm{~Hz}$ 正弦波加振結果
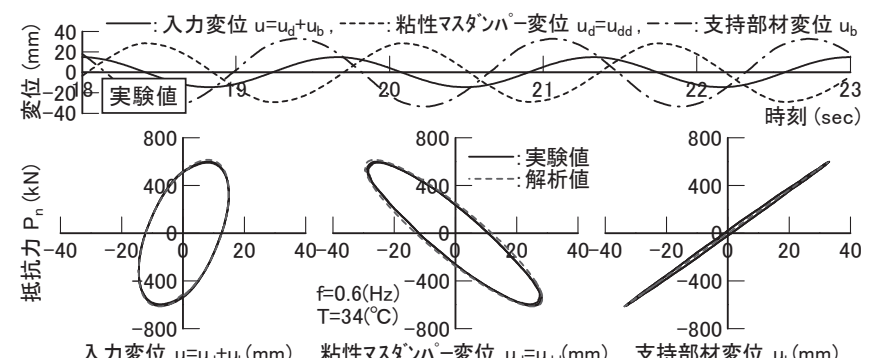

入力変位 $u=u_{d}+u_{b}(m m)$ 粘性マスダンパー変位 $u_{d}=u_{d d}(m m)$ 支持部材变位 $u_{b}(m m)$ 図 $13 F_{r}=$ 約 $800 \mathrm{kN}$ 、振幅 $15 \mathrm{~mm}$ 、振動数 $0.6 \mathrm{~Hz}$ 正弦波加振結果

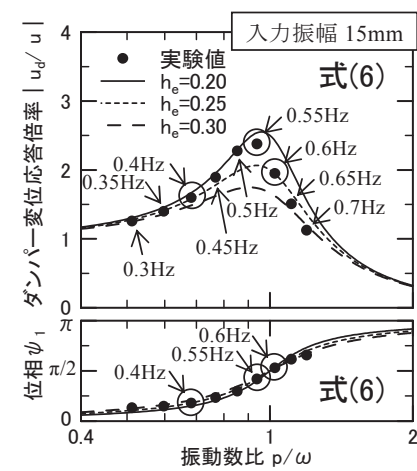

(a) 粘性マスダンパー: $u_{d}$

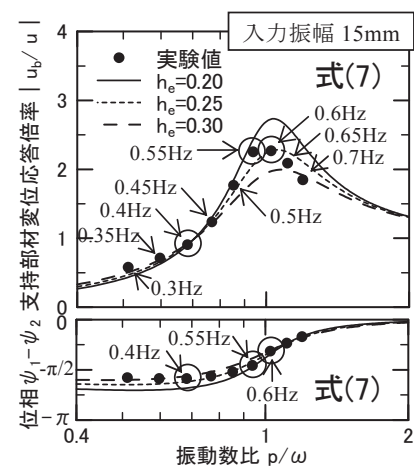

(b) 支持部材 : $u_{b}$
図 14 入力変位 $u=u_{d}+u_{b}$ に対寸る変位応答倍率と位相

FRTVMD の固有円振動数付近の共振域で、粘性マスダンパーの減衰 係数 $c_{d}\left(\dot{u}_{d d}\right)$ の非線形に依存した等価な減衰定数 $h_{e}$ が、小さくなる現 象についても確認することができた。FRTVMDの固有円振動数より 高振動数側の加振に対しては、支持部材変位の振幅と位相が入力変 位に近づくため、粘性マスダンパーの変位応答倍率が小さくなる現 象であることがわかる。図 11,12,13 中に示寸支持部材の実験值は、 大振幅となる変形で多少履歴減衰を有してはいるが、本実験で用い た FRTVMD 解析諸元（減衰係数 $c_{d}\left(\dot{u}_{d d}\right)$ 、等価質量 $m_{i 1}$ 、支持部材剛 性 $k_{b}$ 、制限荷重 $F_{r}$ ）を精度良く評価することによって、実験值（実 線）と解析值（破線）は良い整合性を示すことができた。

図 15,16 に制限荷重 $F_{r}=$ 約 $400 \mathrm{kN}$ （回転滑りが生じる場合）におけ る振幅 $15 \mathrm{~mm}$ の振動数 $0.55,0.6 \mathrm{~Hz}$ の正弦波加振結果（定常部分： $18 \mathrm{~s}$ から 23s）を示す。図中の変位の時刻歷波形は実験值を示し、抵抗力 $P_{n}$ の時刻歴波形および履歴中の解析值（破線）は、減衰係数 $c_{d}\left(\dot{u}_{d d}\right)$ の非線形性や回転すべり状態による判定条件を考慮して時刻歷解析 により算定を行った結果を示している。

約 $400 \mathrm{kN}$ で回転滑りが生じる図 15,16 の実験結果は、回転滑り摩 擦係数の速度依存性や回転滑りに依存しないボールナット部の等価 質量 $m_{i 0}$ などの影響により、制限荷重 $F_{r}=400 \mathrm{kN}$ 近傍の履歴に多少の 違いを生じていると考えられるが、本実験で用いた FRTVMD の解析 諸元（減衰係数 $c_{d}\left(\dot{u}_{d d}\right)$ 、等価質量 $m_{i 1}$ 、支持部材剛性 $k_{b}$ 、制限荷重
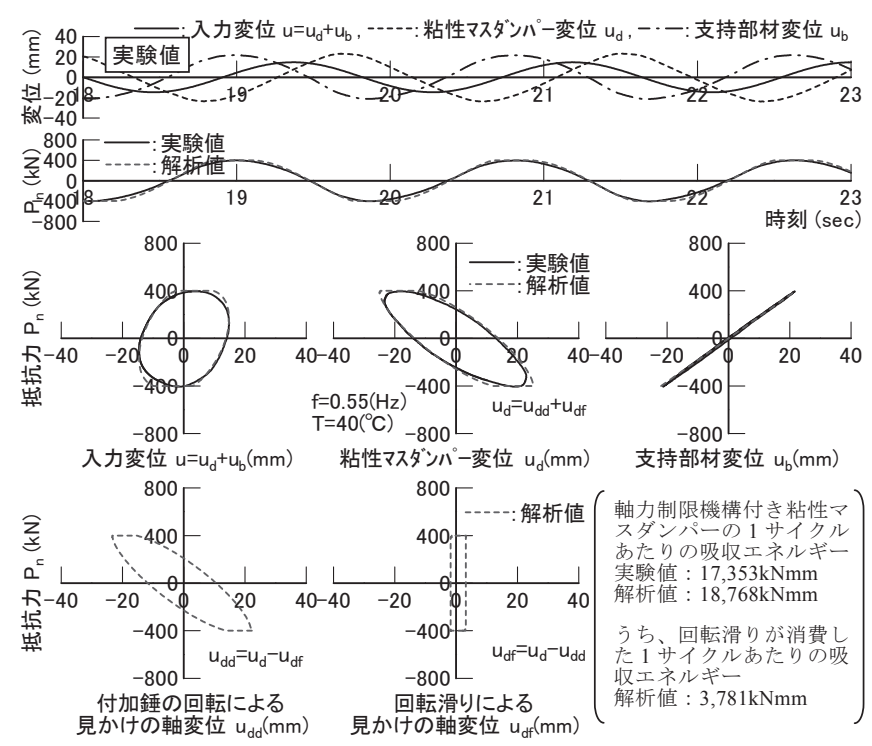

図 $15 F_{r}=$ 約 $400 \mathrm{kN}$ 、振幅 $15 \mathrm{~mm}$ 、振動数 $0.55 \mathrm{~Hz}$ 正弦波加振結果 

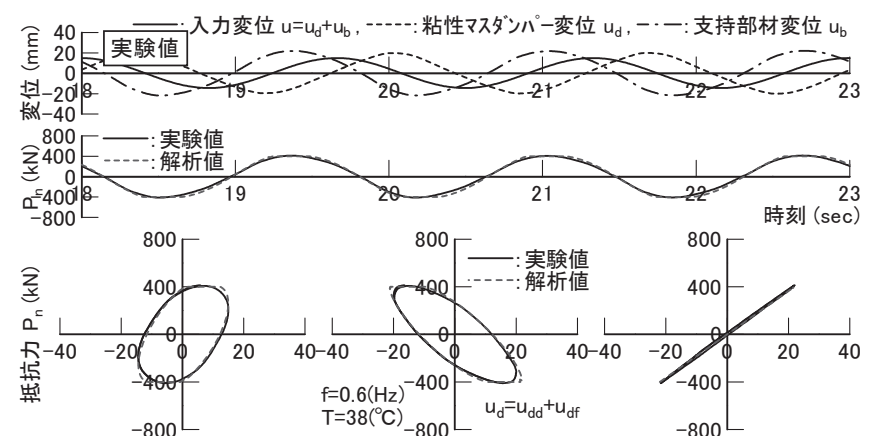

入力変位 $u=u_{d}+u_{b}(m m) \quad$ 粘性マスダンパー変位 $u_{d}(m m) \quad$ 支持部材変位 $u_{b}(m m)$

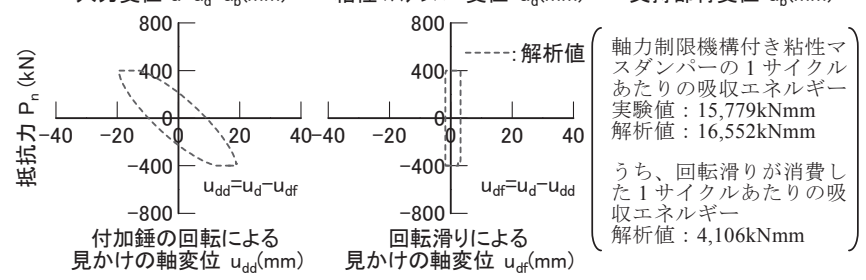

図 $16 F_{r}=$ 約 $400 \mathrm{kN}$ 、振幅 $15 \mathrm{~mm}$ 、振動数 $0.6 \mathrm{~Hz}$ 正弦波加振結果

$F_{r}$ ）を精度良く評価することによって、実験值（実線）と解析值（破 線）は概数良い整合性を示すことができた。制限荷重 $F_{r}=400 \mathrm{kN}$ で回 転滑りが生じている状態は、回転滑り摩擦によるエネルギー消費が 行われており、粘性要素部の減衰係数 $c_{d}\left(\dot{u}_{d d}\right)$ が吸収するエネルギー と、回転滑り部の摩擦による吸収エネルギーの総和が FRTVMD の吸 収エネルギーとなり、本実験のこのエネルギーに対する回転滑り摩 擦によるエネルギー消費の割合（解析值）は、図 15 で 20.1\%程度、 図 16 で $24.8 \%$ 程度であった。本装置の機構上、回転すべり部の温度 上昇を測定することはできなかったが、回転すべり部の温度上昇の 推定を行うと 1 サイクルあたり図 15 で $0.9^{\circ} \mathrm{C}$ 程度、図 16 で $1.0^{\circ} \mathrm{C}$ 程 度であると考えられる。

\section{4. 地震応答波加振による検証}

前章は正弦波で検証を行ったが、本章では地震応答波などのラン ダムな入力に対しても同様な結果が得られるのかを検証する。

図 3 に示寸ように、本実験での FRTVMD は、1 次固有周期 $1.85 \mathrm{~s}$ の構造物（鉄骨造 15 階建て）を想定したチューニング（質量比 0.07 程度の変位応答倍率最適調整条件付銶B) $)$ となっているため、この制 振構造モデルの地震応答解析から得られた 5 階の層間変位時刻歴応 答波を振幅調整しアクチュエータの変位入力として実験を行うもの とする。入力地震波としては、EL CENTRO NS 0.5m/s, TAFT EW 0.5 $\mathrm{m} / \mathrm{s}$ を用いた。

図 17,18 に、制限荷重 $F_{r}=$ 約 $800 \mathrm{kN}$ に設定した場合（回転滑りを生 じさせない場合）における実験值と解析值の比較（EL CENTRO NS 0.5 $\mathrm{m} / \mathrm{s}$, TAFT EW $0.5 \mathrm{~m} / \mathrm{s}$ の 5 階層間変位時刻歴応答波振幅調整入力によ る結果）を示し、図 19,20に、制限荷重 $F_{r}=$ 約 $400 \mathrm{kN}$ （回転滑りが生 じる場合）における実験值と解析值の比較（図 17,18 と同じ入力）を 示す。図中の変位の時刻歴波形は実験值を示し、解析值は減衰係数 $c_{d}\left(\dot{u}_{d d}\right)$ の非線形性や回転すべり状態による判定条件を考慮して時刻 歴解析により算定を行った結果を示している。

回転滑りが生じない図 17,18 の結果より、入力に用いた 5 階の層間 変位波形は、 1 次固有周期 $1.85 \mathrm{~s}$ の成分を持った応答波であるため、 本実験での FRTVMD の諸元 $\left(m_{i 1}=1,350\right.$ ton, $k_{b}=18,200 \mathrm{kN} / \mathrm{m}, \omega=3.67$
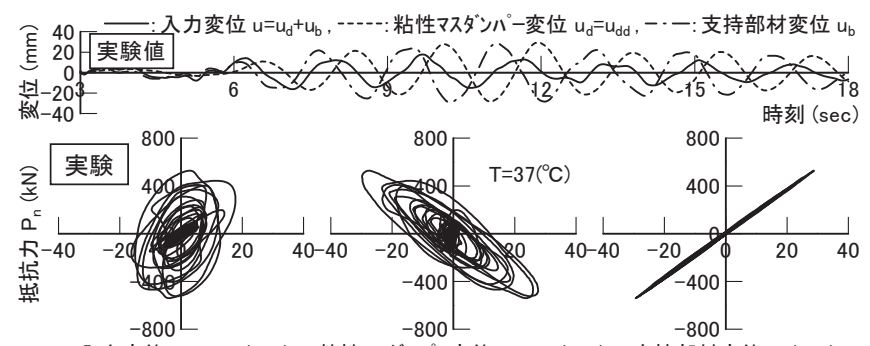

入力変位 $u=u_{d}+u_{b}(m m)$ 粘性マスダンパー变位 $u_{d}=u_{d d}(m m)$ 支持部材変位 $u_{b}(m m)$

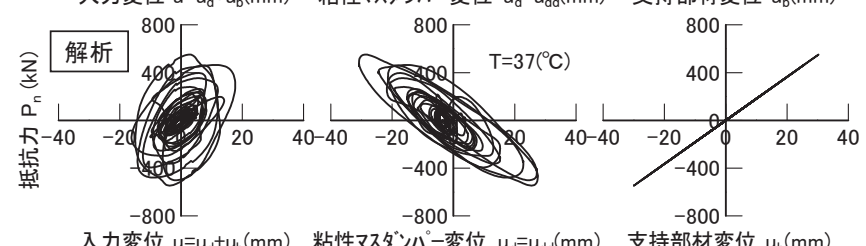

入力変位 $u=u_{d}+u_{b}(m m)$ 粘性マスダンパー変位 $u_{d}=u_{d d}(m m)$ 支持部材変位 $u_{b}(m m)$

図 17 実験と解析の比較（EL CENTRO NS $0.5 \mathrm{~m} / \mathrm{s}$ の 5 階応答波）
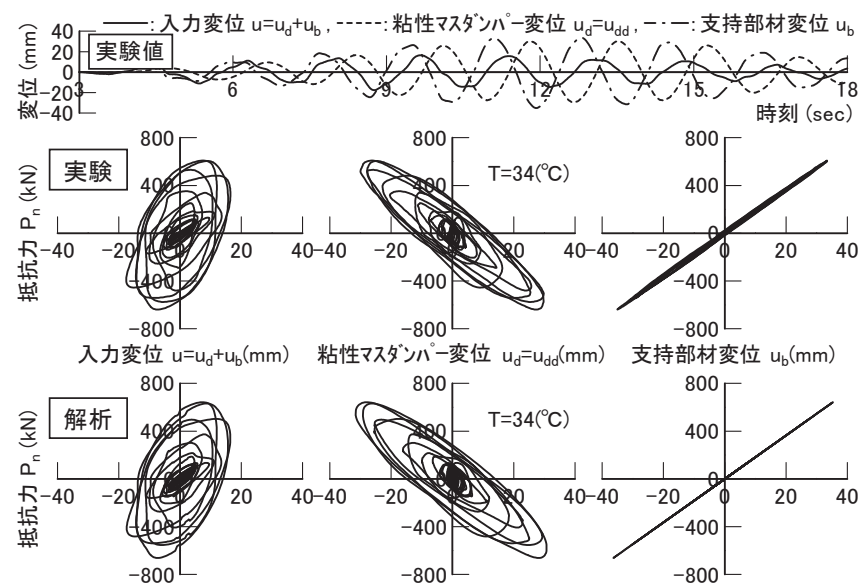

入力変位 $u=u_{d}+u_{b}(m m)$ 粘性マスダンパー変位 $u_{d}=u_{d d}(m m) \quad$ 支持部材変位 $u_{b}(m m)$

図 18 実験と解析の比較（TAFT EW $0.5 \mathrm{~m} / \mathrm{s}$ の 5 階応答波）
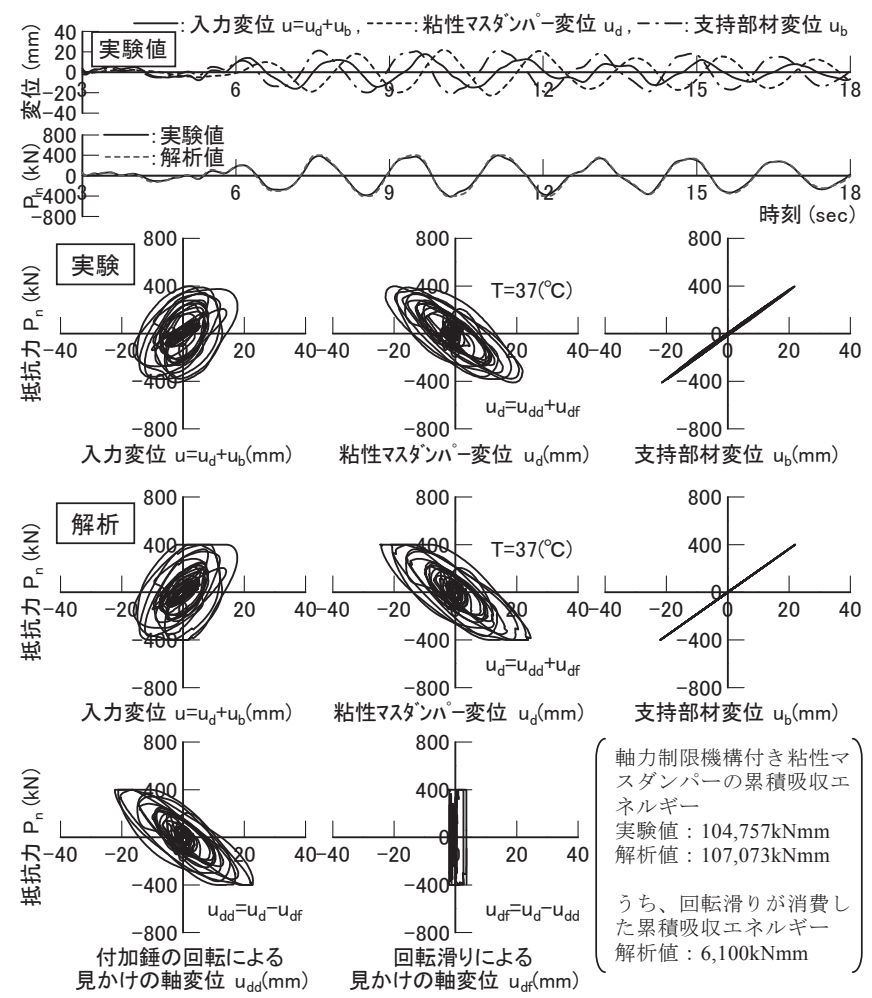

図 19 実験と解析の比較（EL CENTRO NS $0.5 \mathrm{~m} / \mathrm{s}$ の 5 階応答波） 


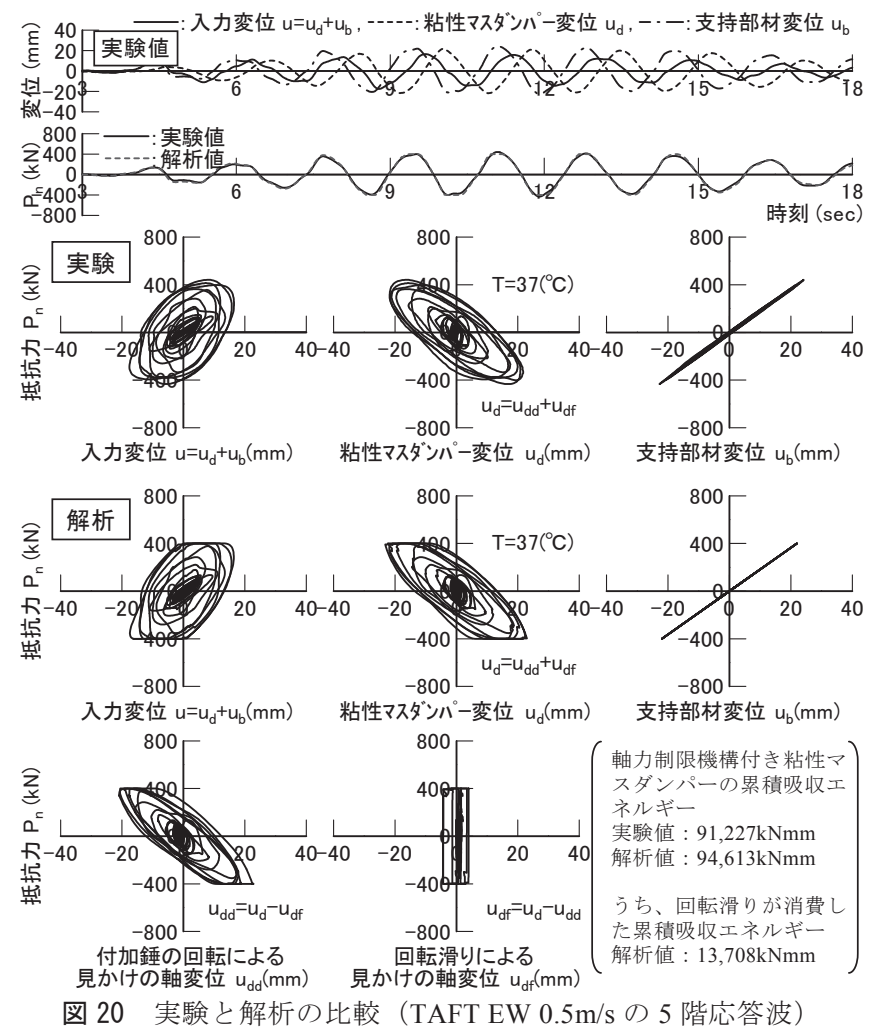

$\mathrm{rad} / \mathrm{s}$ ）で同調する。そのため、軸力制限機構付き粘性マスダンパー の変位 $u_{d}$ と支持部材変位 $u_{b}$ は逆位相で変形し、入力変位 $u=u_{d}+u_{b}$ に 対してそれらの変位が拡大している様子が確認できる。図17,18に示 す粘性マスダンパー部の変位応答倍率を算出すると、平均 1.7 倍程度 であった。前章の図 14 に示す $0.54 \mathrm{~Hz}$ （周期 $1.85 \mathrm{~s}$ ）付近の正弦波加 振実験の結果と比較して小さくなっているが、この理由の 1 つとし ては、入力された 5 階の層間変位波形は 1 次固有周期成分だけでな く様々な周期成分（高次モード）を持っており、FRTVMD 固有周期 付近の成分は同調するが、特に短周期側（高振動数側）に大きく外 れた成分については全く同調しない（支持部材のフィルター効果） 特性の影響があったためと考えられる。

本実験において、調和加振のみでなく地震動などのランダム波加 振に対しても、高次モードや過渡応答の影響により、正弦波入力に よる共振域の応答倍率とまではいかないものの FRTVMD 固有周期付 近の周期帯については有効に同調効果を発揮することが確認でき、 また、本実験で用いた FRTVMD の解析諸元（減衰係数 $c_{d}\left(\dot{u}_{d d}\right)$ 、等 価質量 $m_{i 1}$ 、支持部材剛性 $k_{b}$ 、制限荷重 $F_{r}$ ) を精度良く評価するこ とによって、正弦波加振結果と同様、実験值と解析值は良い整合性 を示すことができた。

次に、約 400kN で回転滑りが生じる場合の考察を行う。図 19,20 の結果より、図 15,16 の正弦波加振結果と同様、回転滑り摩擦係数 の速度依存性や回転滑りに依存しないボールナット部の等価質量 $m_{i 0}$ などの影響により、制限荷重 $F_{r}=400 \mathrm{kN}$ 近傍の履歴に多少の違いを 生じていると思われるが、本実験で用いた式(5)の FRTVMD の解析 諸元（減衰係数 $c_{d}\left(\dot{u}_{d d}\right)$ 、等価質量 $m_{i 1}$ 、支持部材剛性 $k_{b}$ 、制限荷重 $\left.F_{r}\right)$ を精度良く評価することによって、実験值と解析值は概ね良い 整合性を示すことができた。図 17,18 で示す回転滑りが生じない結 果と比較して、回転滑りが生じるまでの時間は、図 17,18 の回転滑
りが生じない結果と同じ軌跡をたどり、制限荷重 $F_{r}=400 \mathrm{kN}$ で回転滑 りが生じている状態は、回転滑り摩擦によるエネルギー消費も粘性 要素部のエネルギー吸収と同時に行われるため、地震動などのラン ダム波加振に対しても、有効に同調効果を発揮し、かつ最大軸力を 制限できる特徴であることがわかる。また本実験における回転滑り によるエネルギー消費の全消費エネルギーに対する割合（解析值） は、回転滑りを生じている時間の全継続時間に占める割合にも関係 し、図 19 で $5.7 \%$ 程度、図 20 で $14.5 \%$ 程度であった。回転す心゙り部 の温度上昇の推定を行うと図 19 で $1.4^{\circ} \mathrm{C}$ 程度、図 20 で $3.2^{\circ} \mathrm{C}$ 程度で あると考えられる。

\section{1 自由度系構造物に対する検討}

本章では、軸力制限機構を適用した場合の制振効果の利点をわか りやすく検討するため、FRTVMD を 1 自由度系構造物に組み込んだ 検討を行うものとする。建物モデルは、第 4 章で検討を行った 1 次 固有周期 $1.85 \mathrm{~s}$ の 15 階建て $\mathrm{S}$ 造モデル（基準階面積 $700 \mathrm{~m}^{2}$ 程度、各 階質量 550ton）とし、このモデルを 1 自由度系に縮約すると等価質 量 $M_{s}$ と等価剛性 $K_{s}$ は、 $6,387 \mathrm{ton}$ と $73,675 \mathrm{kN} / \mathrm{m}$ となる。この主系に FRTVMD（質量比 0.07 の変位応答倍率最適調整条件付緑 $\left.{ }^{\mathrm{B}}\right)$ ）を組み込 んだ解析モデルを図 21 に示す。なお主系の構造減衰定数は、0.01 と し、検証用地震動は EL CENTRO NS $0.5 \mathrm{~m} / \mathrm{s}$, TAFT EW $0.5 \mathrm{~m} / \mathrm{s}$ とする。 $\left(M_{s}, C_{s}, K_{s}, m_{i 1}, c_{d}, k_{b}\right.$ は線形とする。)

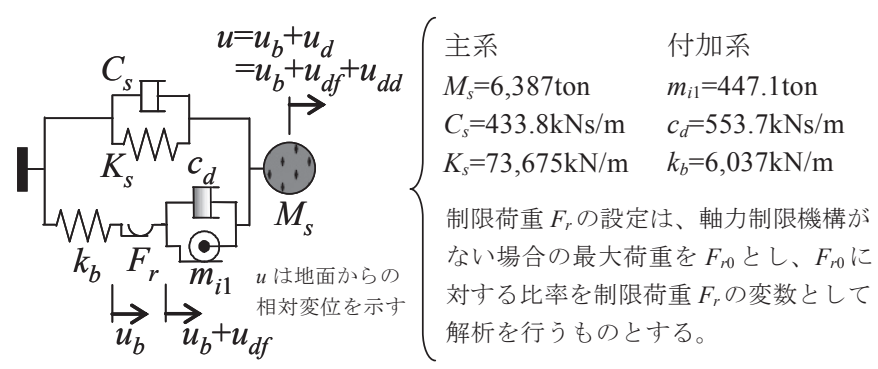

図 21 解析モデル (質量比 0.07 の変位応答倍率最適調整条件付録 B)

図 22 と図 23 に、軸力制限比（FRTVMD 軸力制限值の軸力非制限 同調粘性マスダンパー最大軸力に対寸る比）の違いにおける最大応 答值の結果を示す。（図中の○印は、図 24,25 に示寸応答波形結果の ケースである。）図 22,23 より、軸力制限比が小さくなるほど軸力 制限機構の回転滑り摩擦による消費エネルギー比率が増大し、最大 層間変位や最大加速度応答に関しては、EL CENTRO NS $0.5 \mathrm{~m} / \mathrm{s}$ の場 合、軸力制限比が 0.70 程度まで、TAFT EW $0.5 \mathrm{~m} / \mathrm{s}$ の場合は、軸力 制限比が 0.85 程度まで、最大層間変位、最大加速度応答ともに一定

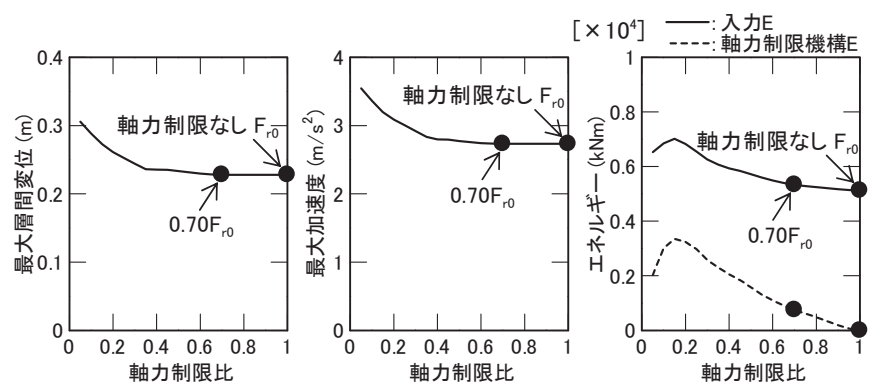

(a) 最大層間変形

(b) 最大加速度

(c) エネルギー応答

図 22 EL CENTRO NS $0.5 \mathrm{~m} / \mathrm{s}$ における最大応答值 
值を示し、軸力制限比がこの值を下回ると徐々に増大しはじめ、あ る軸力制限比から急激に増大寸る傾向が見られた。

図 24 に、TAFT EW $0.5 \mathrm{~m} / \mathrm{s}$ における軸力制限機構がない場合の応

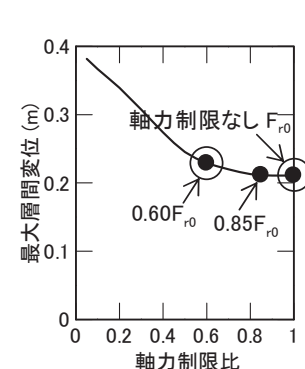

(a) 最大層間変形

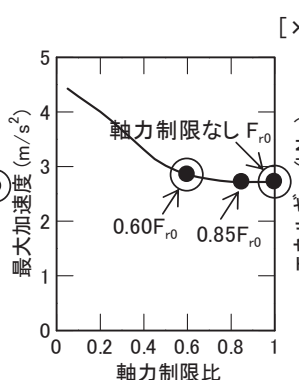

(b) 最大加速度

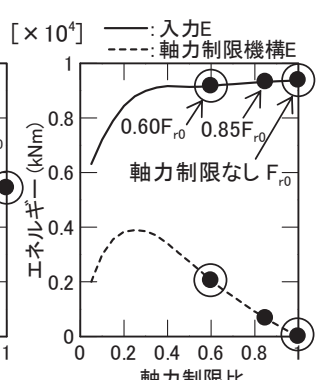

(c) エネルギー応答
図 23 TAFT EW $0.5 \mathrm{~m} / \mathrm{s}$ における最大応答值
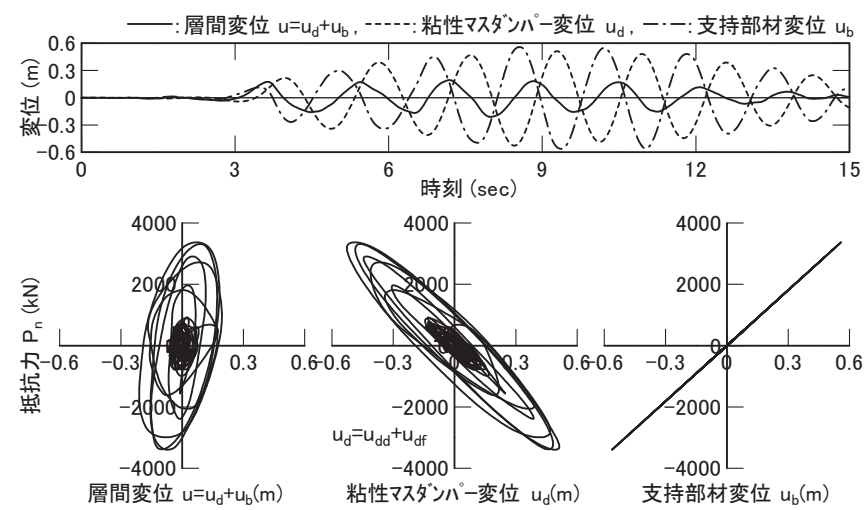

図 24 軸力制限機構がない場合の応答（TAFT EW $0.5 \mathrm{~m} / \mathrm{s}$ )
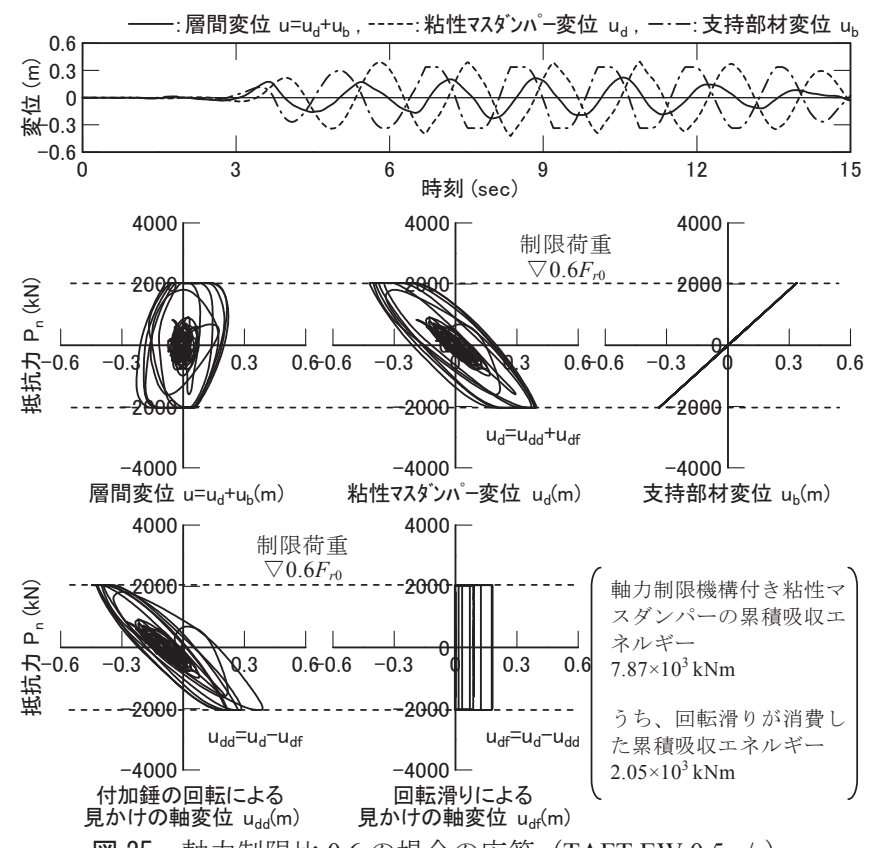

図 25 軸力制限比 0.6 の場合の応答（TAFT EW $0.5 \mathrm{~m} / \mathrm{s}$ )

表 2 軸力制限機構の有無 (図 24,25) によるエネルギー応答比較

\begin{tabular}{|c|c|c|c|}
\hline \multicolumn{2}{|c|}{} & 図 24 (制限なし) & 図 25 (制限あり) \\
\hline \multicolumn{2}{|c|}{ 主系構造減衰エネルギー } & $1.06 \times 10^{3} \mathrm{kNm}$ & $1.27 \times 10^{3} \mathrm{kNm}$ \\
\hline \multirow{2}{*}{$\begin{array}{l}\text { 軸力制限機構 } \\
\text { 付き粘性マス }\end{array}$} & 全体 E & $8.30 \times 10^{3} \mathrm{kNm}$ & $7.87 \times 10^{3} \mathrm{kNm}$ \\
\cline { 2 - 4 } ダンパー & 粘性要素部 E & $8.30 \times 10^{3} \mathrm{kNm}$ & $5.83 \times 10^{3} \mathrm{kNm}$ \\
\cline { 2 - 4 } & 軸力制限機構 E & - & $2.05 \times 10^{3} \mathrm{kNm}$ \\
\hline
\end{tabular}

答波形を示し、図 25 に、TAFT EW $0.5 \mathrm{~m} / \mathrm{s}$ における軸力制限比が 0.6 の場合の応答波形の結果を示す。また表 2 には、これらのエネルギ 一応答結果の比較を示寸。図 25 より、軸力制限比 0.6 の結果は、軸 力制限機構（回転滑り）に変形 $u_{d f}$ が生じ、ダンパー抵抗力に依存す る支持部材の変形 $u_{b}$ が頭打ちとなるが、図 24 に示寸軸力制限機構が ない結果と同様、軸力制限機構付き粘性マスダンパー変位 $u_{d}$ と支持 部材変位 $u_{b}$ は逆位相となり、軸力制限機構がない同調粘性マスダン パーの性質は保持されている。表 2 に注目すると、軸力制限機構が ない場合では粘性要素部のみでエネルギー吸収を、軸力制限比 0.6 の 場合では、粘性要素部と軸力制限機構の 2 箇所でエネルギーを吸収 し、その足し合わせたエネルギー量が、軸力制限機構がない場合と 同等程度であった。以上のような結果から、FRTVMD がダンパー最 大軸力を抑えつつ、同等程度の応答低減効果を得られる 1 つの理由 であると考えられる。

\section{6. まとめ}

本論文では、FRTVMD の実大要素加振実験により、理論および解 析手法の妥当性の検証を行うとともに、FRTVMDを主系の構造体に 組み込み、軸力制限機構を適用した場合の制振効果の利点について 検討を行った。得られた成果は以下の通りである。

(1) 本論文では、速度に依存する粘性減衰力と加速度に依存する慣性 力のそれぞれ位相が異なる力を足し合わせた合力を頭打ちにする ために、回転滑り機構を利用した軸力制限機構付き粘性マスダン パーを提案した。また、その回転滑り材に与える軸力を自在に管 理することで、制限荷重を自在にコントロールできることを実大 要素加振実験により示した。

(2) FRTVMD の詳細な解析モデルを構築し、本害験での解析諸元（減 衰係数 $c_{d}\left(\dot{u}_{d d}\right)$ 、等価質量 $m_{i 1}$ 、支持部材剛性 $k_{b}$ 、制限荷重 $\left.F_{r}\right)$ を 精度良く評価することによって、調和加振のみでなく地震動など のランダム波加振においても、実験值と解析值は良い整合性を示 すことを確認した。

(3) 2 種類の入力と軸力制限比をパラメータとして FRTVMD の 1 自 由度系構造物に組み込んだ場合の計算例を示した。FRTVMD は、 軸力制限されるまでは、軸力制限がない同調粘性マスダンパーの 性質 (同調効果) を保持し、軸力制限されている状態は、粘性要 素部と軸力制限機構の 2 箇所でエネルギーを吸収するため、本論 文で検討した 2 種類の入力特性においては、結果的に 0.6 倍程度 の軸力制限比であれば軸力制限機構がない場合と同等の最大層間 変位や最大加速度応答に抑えることができ、本提案機構の優位性 が得られる範囲であることがわかった。

\section{参考文献}

1) 斉藤賢二, 栗田哲, 井上範夫 : 慣性接続要素を利用した線形粘性ダンパー による 1 質点構造の最適応答制御と Kelvin モデル化手法に関寸る考察, 構造工学論文集, Vol53B, pp.53-66, 2007.3

2) 斉藤賢二, 中南滋樹, 木田英範, 井上範夫 : 慣性接続要素と最適化された 柔バネ要素と粘性要素を有する一層応答制御システムの振動実験, 構造工 学論文集, Vol.54B, pp.623-634, 2008.3

3) 中南滋樹, 木田英範, 斉藤賢二, 五十子幸樹, 井上範夫 : 2 重同調粘性マス ダンパーシステムによる一層応答制御システムの振動実験(その 1 実験概 要と調和加振に対する検証), 日本建築学会大会学術講演梗概集, B-2, pp.417 $418,2009.8$ 
4) 木田英範, 中南滋樹, 斉藤賢二, 五十子幸樹, 井上範夫 : 2 重同調粘性マス ダンパーシステムによる一層応答制御システムの振動実験(その 2 調和加 振と地震波入力に対する検証), 日本建築学会大会学術講演梗概集, B-2, pp.419$420,2009.8$

5) 荒井達朗, 油川健樹, 五十子幸樹, 堀則男, 井上範夫 : 同調粘性マスダン パーの有効性の検証と弾塑性構造物一の適用性, 日本建築学会構造系論 文集, 第 74 巻, 第 645 号, pp.1993-2002, 2009.11

6) 木田英範, 中南滋樹, 斉藤賢二, 五十子幸樹, 井上範夫 : 実大加振実験に 基づく同調粘性マスダンパーの解析モデルに関する検証, 構造工学論文集, Vol.56B, pp.137-146, 2010.3

7) 木田英範, 中南滋樹, 斉藤賢二, 五十子幸樹, 井上範夫 : 多重同調粘性マ スダンパー制振システムとその応答制御法, 日本建築学会構造系論文集, 第 74 巻, 第 643 号, pp.1575-1583, 2009.9

8）杉村義文, 斉藤賢二, 五十子幸樹, 井上範夫 : 同調粘性マスダンパーを用い た多層建築構造物の応答制御に関する一考察, 構造工学論文集, Vol.56B, pp. 153-161, 2010.3

9) 墨山智大, 荒井達朗, 池永昌容, 五十子幸樹, 井上範夫 : 同調粘性マスダン パー制振システムを組み込んだ構造物に関する研究(その1リリーフ機構の 有効性に関寸る検討), 日本建築学会大会学術講演梗概集, B-2, pp.449-450, 2010.9

10) J.P.Den Hartog: Mechanical Vibrations,4thed., over,New York, 1985

11) 背戸一登 : 構造物の振動制御, コロナ社, 2005.3

12) Crandall,S.E.and Mark,W.D.:Random Vibration in Mechanical Systems, Academic Press, 1963

13) 浅見敏彦, 西原修, Amr M. Baz, 木村文義 : 減衰系に取り付ける動吸振器 の $\mathrm{H} 2$ 最適化における代数的厳密解, 日本機械学会論文集( $($ 編), 67 巻, 655 号, pp.7-13, 2001.3

14) 磯田和彦, 半澤徹也, 深沢剛司, 福喜多輝 : 過負荷防止機構を持つ慣性質量 ダンパーの開発(その 1 開発目的とダンパーの概要), 日本建築学会大会学術 講演梗概集, B-2, pp.453-454, 2010.9

15）新垣忠志, 黒田英二, 有馬文昭, 井上豊, 馬場研介：ボール放じを用いた制 震装置の開発(その 1), 日本建築学会技術報告集, 第 8 号, pp.239-224, 1999.6

16）中南滋樹, 黒田英二, 有馬文昭, 鈴木良二, 井上豊, 馬場研介 : 増幅機構付 き減衰装置の開発(その 6 見掛けの粘度試験による粘性減衰力の評価法), 日 本建築学会大会学術講演梗概集, B-2, pp.873-874, 2000.9

\section{付録 A 軸力制限機構付き粘性マスダンパー解析モデルの設定根拠}

軸力制限機構付き粘性マスダンパーの装置剛性（支持部材に比べ十分に剛で ある）を剛として考える場合、装置の軸方向に発生寸る全抵抗力 $P_{n}$ は、図 $\mathrm{A} 1$ に示寸ボール㸚じ軸部の力の釣り合い ${ }^{15}$ から誘導され、ボールねじ軸部には 式(A1)に示す力が作用する。この全抵抗力 $P_{n}$ は、ボールねじ部の摩擦による

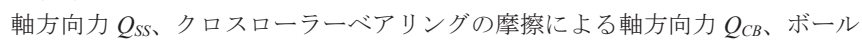
ナット部の回転慣性による軸方向力 $Q_{i 0}$ 、回転滑りによる軸方向力 $Q_{f}$ を介して 発生する各軸方向力（粘性体のせん断抵抗による軸方向力 $Q_{v}$ 、シール、ラジ アルベアリングの摩擦による軸方向力 $Q_{s i}, Q_{R B}$ 、付加錘の回転慣性による軸方 向力 $\left.Q_{i 1}\right)$ の成分の総和である。ボール称じ部の摩擦 $Q_{s s}$ およびクロスローラ 一ベアリングの摩擦 $Q_{C B}$ は全抵抗力 $P_{n}$ に依存する。

$$
\begin{aligned}
P_{n} & =Q_{S S}+Q_{C B}+Q_{i 0}+Q_{v}+Q_{s i}+Q_{R B}+Q_{i 1} \\
& =Q_{S S}+Q_{T}
\end{aligned}
$$

$\left(\right.$ 回転滑りなし: $u_{d f}=0, u_{d}=u_{d d},\left|Q_{v}+Q_{s i}+Q_{R B}+Q_{i i}\right|<\left|Q_{f}\right|$

回転滑りあり: $u_{d}=u_{d f}+u_{d d}, Q_{v}+Q_{s i}+Q_{R B}+Q_{i 1}=Q_{f}$

式(A1)に示寸ボールねじ部の摩擦要素以外の軸方向力 $Q_{T}$ の負荷ボールに働 く衩じ軸接線方向力は、図 $\mathrm{A} 1$ より $Q_{T} \cdot \tan \varphi$ で表される。㸚じ軸中心から負荷 ボール中心までの距離を $r_{S S}$ とすると、㸚じ軸中心周りのモーメントの釣り合 いより次式が成立する。ここで、一部の特殊な条件、つまり回転慣性が駆動 カとして作用する場合 ${ }^{6}$ のみ正効率の釣り合い条件となる。

$$
\begin{aligned}
Q_{T} \cdot \tan \varphi \times r_{S S} & =Q_{C B} \times r_{C B}+I_{0} \ddot{\theta} \\
& { }_{r} Q_{v} \times r_{v}+{ }_{r} Q_{s i} \times r_{s i}+{ }_{r} Q_{R B} \times r_{R B}+I_{1} \ddot{\theta}_{d}
\end{aligned}
$$

$\left(\begin{array}{l}\text { 回転滑りなし: } \theta_{f}=0, \theta=\theta_{d},\left|{ }_{r} Q_{v} r_{v}+{ }_{r} Q_{s i} r_{s i}+{ }_{r} Q_{R B} r_{R B}+I_{1} \ddot{\theta}_{d}\right|<\left|{ }_{r} Q_{f} r_{f}\right| \\ \text { 回転䄇りあり }: \theta=\theta_{f}+\theta_{d},{ }_{r} Q_{v} r_{v}+{ }_{r} Q_{s i} r_{s i}{ }_{r} Q_{R B} r_{R B}+I_{1} \ddot{\theta}_{d}={ }_{r} Q_{f} r_{f}\end{array}\right.$

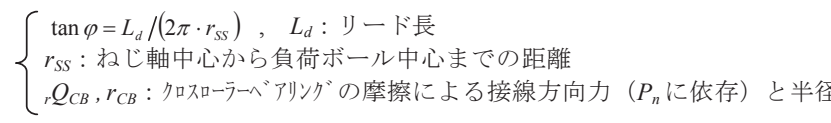
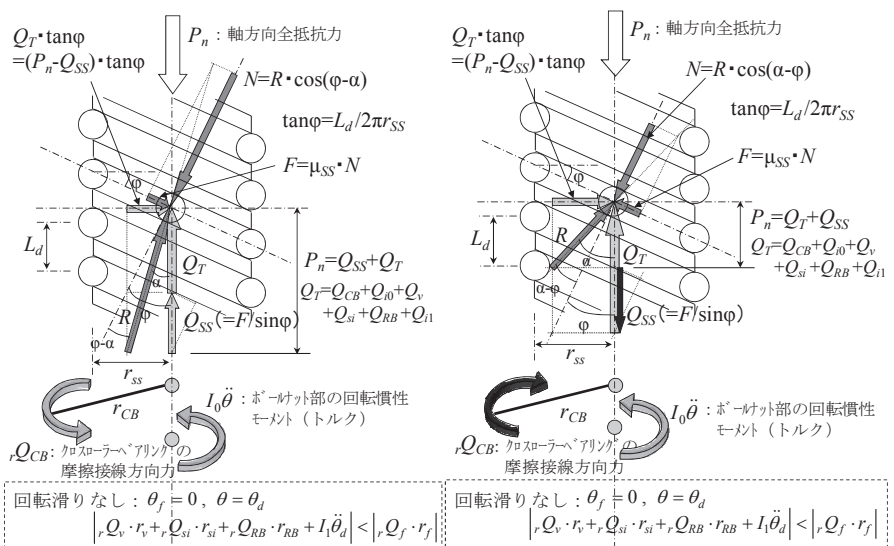

$\left|r Q_{v} \cdot r_{v}+Q_{r} Q_{s i} \cdot r_{s i}+Q_{r} Q_{R B} \cdot r_{R B}+I_{1} \ddot{\theta}_{d}\right|<\mid r Q_{f} \cdot r_{f}$

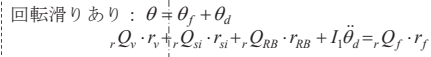

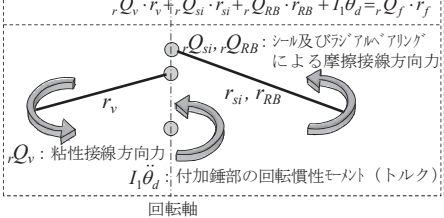

(a) 逆効率（直線 $\rightarrow$ 回転）

図A1 ボールねじ軸部での釣り合い

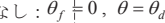

$\left|{ }_{r} Q_{v} \cdot r_{v}+{ }_{r} Q_{s i} \cdot r_{s i}+{ }_{r} Q_{R B} \cdot r_{R B}+I_{1} \ddot{\theta}_{d}\right|<\left|{ }_{r} Q_{f} \cdot r_{f}\right|$

回転滑りあり $\theta=\theta_{f}+\theta_{0}$ ${ }_{r} Q_{v} \cdot r_{v}+{ }_{i}, Q_{s i} \cdot r_{s i}+{ }_{r} Q_{R B} \cdot r_{R B}+I_{1} \ddot{\theta}_{d}=Q_{r} Q_{f} \cdot r_{f}$

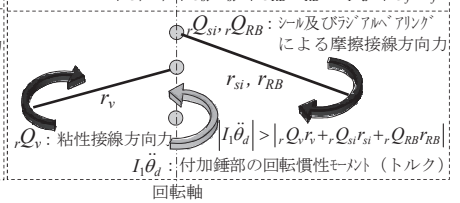

(b) 正効率（回転 $\rightarrow$ 直線）

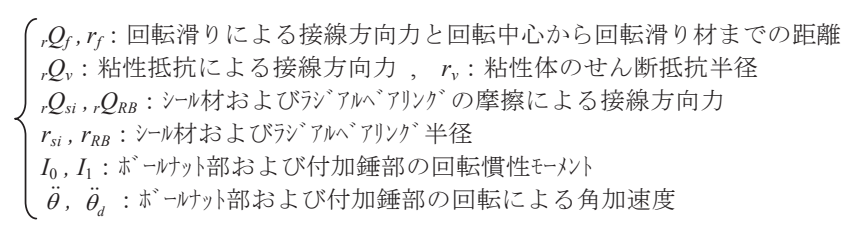

回転しながら装置の軸方向全抵抗力 $P_{n}$ を、内筒（固定部）に伝達する機構 であるクロスローラーベアリング部における力の釣り合いは、クロスローラ 一ベアリングの摩擦係数を $\mu_{C B}$ とすると、軸方向全抵抗力 $P_{n}$ に $\mu_{C B}$ を乗じた 值が、クロスローラーベアリングの摩擦による接線方向力 ${ }_{r} Q_{C B}$ となることか ら、式(A3)を得る。

逆効率 : ${ }_{r} Q_{C B}=\mu_{C B} \cdot P_{n}$

正効率 : ${ }_{r} Q_{C B}=-\mu_{C B} \cdot P_{n}$

...(A3a)

...(A3b)

回転すべり部による接線方向力 ${ }_{r} Q_{f}$ は、回転すべり部の摩擦係数を $\mu_{f} 、$ 皿バ ネにより回転滑り部に与える導入軸力を $N_{f}$ とした場合、次式で表わされる。

$$
{ }_{r} Q_{f}=\mu_{f} \cdot N_{f}
$$

構成材料である粘性体（ジメチルシリコーンオイル）は、付加錘と一緒に 回転する部材と固定されている内筒との隙間 $d y$ に充填されている。地震等の 外乱により、付加錘と一緒に回転する部材内表面が速度 $V_{r}$ で回転すると、粘 性体にはせん断歪速度 $V_{s}\left(=V_{r} / d y\right)$ が生じるため、見かけの動粘度 $\eta$ に依存し て、接線方向にせん断応力 $\tau$ が発生する。粘性抵抗による接線方向力 ${ }_{r} Q_{v}$ は、 接線方向のせん断応力 $\tau$ に、粘性体のせん断有効面積 $A$ を乗じたものである ので、

$$
{ }_{r} Q_{v}=\tau \cdot A=\eta \cdot V_{s} \cdot A
$$

と表される。1リード長だけ変位すれば、付加錘と一緒に回転する部材内表 面は $2 \pi r_{v}$ だけ回転するため、軸方向速度 $\dot{u}_{d d}$ に対する速度増幅率は $S_{v}=2 \pi r_{v} / L_{d}$ となるので、次式が成り立つ。

$$
V_{s}=V_{r} / d y=S_{v} \cdot \dot{u}_{d d} / d y=2 \pi r_{v} \cdot \dot{u}_{d d} /\left(L_{d} \cdot d y\right)
$$

式(A5)のせん断歪速度と温度に依存する見かけの動粘度 ${ }^{15), 16)} \eta$ は、次式に て表現される。

$$
\eta=\xi \cdot \frac{\eta_{T}}{1+b\left|V_{s}\right|^{\gamma}} \quad, \quad \eta_{T}=1.02^{(25-T)} \times \eta_{25}
$$
$\left\{\begin{array}{l}\xi: \text { 繰り返し依存係数, } b, \gamma: \text { 見かけの動粘度を計算する係数 } \\ \eta_{T}: \text { 粘性体温度 } T^{\circ} \mathrm{C} \text { 時の粘度 }, \eta_{25}: \text { 粘性体温度 } 25^{\circ} \mathrm{C} \text { 時の粘度 }\end{array}\right.$

シール材の摩擦による接線方向力 ${ }_{r} Q_{s i}$ は、シール材の単位長さ当りの摩擦 力を $f_{s i}$ 、シール材の半径を $r_{s i}$ 、シール材の個数を $n$ とした場合、次式のよう に表される。

${ }_{r} Q_{s i}=n \times f_{s i} \times 2 \pi \cdot r_{s i}$ 
ラジアルベアリングの摩擦による接線方向力 ${ }_{r} Q_{R B}$ は、ラジアルベアリング の摩擦係数を $\mu_{R B}$ 、ラジアルベアリングの支える重量を $W$ とした場合、次式 のように表される。

$$
{ }_{r} Q_{R B}=\mu_{R B} \cdot W
$$

ボールナット部の回転慣性によるトルク $I_{0} \ddot{\theta}$ および付加錘部の回転慣性に よるトルク $I_{1} \ddot{\theta}_{d}$ は、ボールナット部（ボールナットと一緒に回転する部材を 含む）および付加錘部（付加錘と一緒に回転する部材を含む）の質量が回転 することにより得られ、角加速度 $\ddot{\theta}, \ddot{\theta}_{d}$ は、装置に入力される軸方向加速度 $\ddot{u}_{d}, \ddot{u}_{d d}$ に $2 \pi / L_{d}$ を乗じたものであることから、

$$
I_{0} \ddot{\theta}=I_{0} \cdot 2 \pi \cdot \ddot{u}_{d} / L_{d}, \quad I_{1} \ddot{\theta}_{d}=I_{1} \cdot 2 \pi \cdot \ddot{u}_{d d} / L_{d}
$$

となる。ボールナットおよび付加錘は中空円筒形状を示しており、ボールナ ットおよび付加錘の実質量 $m_{0}, m_{1}$ 、外半径 $r_{o 0}, r_{o 1}$ 、内半径を $r_{i 0}, r_{i 1}$ とすると $I_{0}=m_{0}\left(r_{o 0}^{2}+r_{i 0}^{2}\right) / 2, \quad I_{1}=m_{1}\left(r_{o 1}^{2}+r_{i 1}^{2}\right) / 2$

となる。式(A3)〜(A11)を式(A2)に代入して整理すると次式を得る。

$$
\begin{aligned}
& \text { 逆効率: } Q_{T}=\mu_{C B} P_{n} \cdot S_{C B}+m_{0}\left(r_{o 0}^{2}+r_{i 0}^{2}\right)\left(2 \pi / L_{d}\right)^{2} \ddot{u}_{d} / 2+\eta A \cdot S_{v}^{2} \dot{u}_{d d} / d y \\
& +2 \pi r_{s i} n f_{s i} \cdot S_{s i}+\mu_{R B} W \cdot S_{R B}+m_{1}\left(r_{o 1}^{2}+r_{i 1}^{2}\right)\left(2 \pi / L_{d}\right)^{2} \ddot{u}_{d d} / 2 \\
& \text { 正効率 : } Q_{T}=-\mu_{C B} P_{n} \cdot S_{C B}+m_{0}\left(r_{o 0}^{2}+r_{i 0}^{2}\right)\left(2 \pi / L_{d}\right)^{2} \ddot{u}_{d} / 2+\eta A \cdot S_{v}^{2} \dot{u}_{d d} / d y \\
& +2 \pi r_{s i} n f_{s i} \cdot S_{s i}+\mu_{R B} W \cdot S_{R B}+m_{1}\left(r_{o 1}^{2}+r_{i 1}^{2}\right)\left(2 \pi / L_{d}\right)^{2} \ddot{u}_{d d} / 2 \\
& \text { ここで、 }\left(S_{C B}=2 \pi r_{C B} / L_{d}, S_{v}=2 \pi r_{v} / L_{d}, S_{s i}=2 \pi r_{s i} / L_{d}, S_{R B}=2 \pi r_{R B} / L_{d}\right. \\
& \left\{Q_{s i}=2 \pi r_{s i} n f_{s i} \cdot S_{s i} \text { と } Q_{R B}=\mu_{R B} W \cdot S_{R B} \text { は } \dot{u}_{d d}\right. \text { と同符号 } \\
& Q_{v}=\eta A \cdot S_{v}^{2} \dot{u}_{d d} / d y, Q_{i 1}=m_{1}\left(r_{o 1}^{2}+r_{i 1}^{2}\right)\left(2 \pi / L_{d}\right)^{2} \ddot{u}_{d d} / 2 \\
& Q_{f}={ }_{r} Q_{f} \cdot 2 \pi \cdot r_{f} / L_{d}=\mu_{f} N_{f} \cdot 2 \pi \cdot r_{f} / L_{d} \text { は } \dot{u}_{d f} \text { と同符号 }
\end{aligned}
$$

ボールねじ部の負荷ボールとリード溝においては、図 A1 に示すように軸 方向全抵抗力 $P_{n}$ とボールねじ部の摩擦要素以外の接線方向力（円周方向力） $Q_{T} \cdot \tan \varphi$ が作用する。 $P_{n}$ と $Q_{T} \cdot \tan \varphi$ との合力 $R$ は、負荷ボールからの抵抗力 $N$ と摩擦力 $F$ との合力と釣り合うので次式が成立する。

逆効率 : $N=R \cdot \cos (\varphi-\alpha)=R \cdot(\cos \varphi \cdot \cos \alpha+\sin \varphi \cdot \sin \alpha)$

正効率 : $N=R \cdot \cos (\alpha-\varphi)=R \cdot(\cos \varphi \cdot \cos \alpha+\sin \varphi \cdot \sin \alpha)$

式(A13)に $\cos \alpha=P_{n} / R, \sin \alpha=Q_{T} \tan \varphi / R=\left(P_{n}-Q_{S S}\right) \tan \varphi / R$ を代入し整理す ると、次式が得られる。

$N=P_{n} \cos \varphi+\left(P_{n}-Q_{S S}\right) \tan \varphi \cdot \sin \varphi$

ボールベアリング部の摩擦係数を $\mu_{S S}$ とすると、ボールねじ部の摩擦力 $F$ は、次式のように表される。

$$
F=\mu_{S S} \cdot N=\mu_{S S} P_{n} \cos \varphi+\mu_{S S}\left(P_{n}-Q_{S S}\right) \tan \varphi \cdot \sin \varphi
$$

したがってボールねじ部の摩擦による軸方向力 $Q_{S S}$ は、式(A16)で表される。 逆効率 : $Q_{S S}=F / \sin \varphi$ より $Q_{S S}=P_{n} \mu_{S S}(1 / \tan \varphi+\tan \varphi) /\left(1+\mu_{S S} \tan \varphi\right) \quad \ldots$ (A16a) 正効率 : $Q_{S S}=-F / \sin \varphi$ より $Q_{S S}=-P_{n} \mu_{S S}(1 / \tan \varphi+\tan \varphi) /\left(1-\mu_{S S} \tan \varphi\right) \ldots(\mathrm{A} 16 \mathrm{~b})$ また、装置に作用するトルク $T_{n}=\left(P_{n}-Q_{S S}\right) \tan \varphi \cdot r_{S S}$ は、軸方向全抵抗力 $P_{n}$ に 依存し、次式のようになる。

逆効率 : $T_{n}=P_{n} \cdot L_{d}\left\{1-\mu_{S S}(1 / \tan \varphi+\tan \varphi) /\left(1+\mu_{S S} \tan \varphi\right)\right\} /(2 \pi)$ 正効率 : $T_{n}=P_{n} \cdot L_{d}\left\{1+\mu_{S S}(1 / \tan \varphi+\tan \varphi) /\left(1-\mu_{S S} \tan \varphi\right)\right\} /(2 \pi)$

軸力制限機構付き粘性マスダンパーの両端に取り付けられるボールジョイ ント部の軸方向力 $P_{n}$ とトルク $T_{B}$ の関係式は、ボールジョイント部の摩擦係

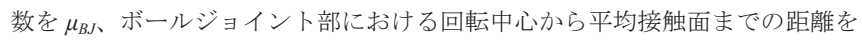
$r_{B J}$ とおくと、

$$
T_{B}=P_{n} \cdot \mu_{B,} \cdot r_{B,}
$$

であるので、式(A17)で示されるトルク $T_{n}$ より式(A18)で示されるトルク $T_{B}$ の ほうが大きい場合、ボールジョイント部で回転することはなく、この条件を満 たすボールジョイント部の摩擦係数は、以下の通りとなる。

$\mu_{B J}>L_{d} \cdot\left\{1+\mu_{S S}(1 / \tan \varphi+\tan \varphi) /\left(1-\mu_{S S} \tan \varphi\right)\right\} /\left(2 \pi \cdot r_{B J}\right)$

本実験での試験体諸元 $L_{d}=20 \mathrm{~mm}, \mu_{S S}=0.002 \sim 0.008$ 程度, $r_{S S}=50 \mathrm{~mm}, r_{B J}=60 \mathrm{~mm}$ より式(A19)に代入し算定すると、 $\mu_{B J}>0.06$ となる。ボールジョイント部は、 鋼材と鋼材の接触面となっており、ボールジョイント部の摩擦係数が少なくと も 0.1 以上あると考えられるため、軸力制限機構付き粘性マスダンパーの発生 トルクによりボールジョイント部が回転することはない。
式(A12)と式(A16)を式(A1)に代入し整理すれば、軸方向全抵抗力 $P_{n}$ に関す る式となる。 $\left(\lambda: Q_{S S}, Q_{C B}\right.$ による等価摩擦係数 $)$

$P_{n}=\lambda \cdot\left(Q_{i 0}+Q_{v}+Q_{s i}+Q_{R B}+Q_{i 1}\right)$

[回転滑りなし： $u_{d f}=0, u_{d}=u_{d d},\left|Q_{v}+Q_{s i}+Q_{R B}+Q_{i 1}\right|<\left|Q_{f}\right|$

回転滑りあり: $u_{d}=u_{d f}+u_{d d}, Q_{v}+Q_{s i}+Q_{R B}+Q_{i 1}=Q_{f}$

$\left\{\begin{array}{l}\text { 逆効率 }: \lambda=1 /\left\{1-\mu_{S S}(1 / \tan \varphi+\tan \varphi) /\left(1+\mu_{S S} \tan \varphi\right)-\mu_{C B} S_{C B}\right\} \\ \text { 正効率 }: \lambda=1 /\left\{1+\mu_{S S}(1 / \tan \varphi+\tan \varphi) /\left(1-\mu_{S S} \tan \varphi\right)+\mu_{C B} S_{C B}\right\} \\ Q_{f}=\mu_{f} N_{f} \cdot 2 \pi \cdot r_{f} / L_{d} \quad\left(\dot{u}_{d f} \text { と同符号 }\right), Q_{v}=\eta A \cdot S_{v}^{2} \dot{u}_{d d} / d y \\ Q_{s i}=2 \pi r_{s i} n f_{s i} \cdot S_{s i}\left(\dot{u}_{d d} \text { と同符号 }\right), Q_{R B}=\mu_{R B} W \cdot S_{R B} \quad\left(\dot{u}_{d d} \text { と同符号 }\right) \\ Q_{i 0}=m_{0}\left(r_{o 0}^{2}+r_{i 0}^{2}\right)\left(2 \pi / L_{d}\right)^{2} \ddot{u}_{d} / 2, Q_{i 1}=m_{1}\left(r_{o 1}^{2}+r_{i 1}^{2}\right)\left(2 \pi / L_{d}\right)^{2} \ddot{u}_{d d} / 2\end{array}\right.$

式(A20)の $Q_{f}$ を、

$F_{r}=\lambda \cdot Q_{f}=\lambda \cdot \mu_{f} N_{f} \cdot 2 \pi \cdot r_{f} / L_{d} \quad\left(\dot{u}_{d f}\right.$ と同符号 $)$

式(A20)の軸加速度 $\ddot{u}_{d}, \ddot{u}_{d d}$ の係数を、

$m_{i 0}=\lambda \cdot m_{0}\left(r_{o 0}^{2}+r_{i 0}^{2}\right)\left(2 \pi / L_{d}\right)^{2} / 2, \quad m_{i 1}=\lambda \cdot m_{1}\left(r_{o 1}^{2}+r_{i 1}^{2}\right)\left(2 \pi / L_{d}\right)^{2} / 2$

式(A20)の軸速度 $\dot{u}_{d d}$ の係数を、

$c_{d}\left(\dot{u}_{d d}\right)=c_{v}\left(\dot{u}_{d d}\right)+c_{f}\left(\dot{u}_{d d}\right)$

$\left\{\begin{array}{l}c_{v}\left(\dot{u}_{d d}\right)=\lambda \cdot \eta A \cdot S_{v}^{2} / d y \\ \left|\dot{u}_{d d}\right| \geq \varepsilon \text { のとき、 } c_{f}\left(\dot{u}_{d d}\right) \cdot \dot{u}_{d d}=\operatorname{sgn}\left(\dot{u}_{d d}\right) \times\left|\lambda\left(Q_{s i}+Q_{R B}\right)\right| \\ \left|\dot{u}_{d d}\right|<\varepsilon \text { のとき、 } c_{f}\left(\dot{u}_{d d}\right) \cdot \dot{u}_{d d}=\mid \lambda\left(Q_{s i}+Q_{R B} \mid \times \dot{u}_{d d} / \varepsilon\right. \\ \varepsilon \text { は微小速度 }\end{array}\right.$

とおけば、最終的に式(A20)は本文中の図 5 と式(2)となる。式(A23)の $Q_{s i}+Q_{R B}$ は、装置の全抵抗力 $P_{n}$ に依存しない摩擦力であり、解析上は、剛塑性の復元 力特性として扱うべきであるが、ここでは十分に小さな速度 $\varepsilon$ を与え、軸速 度の絶対值が $\left|\dot{u}_{d d}\right| \geq \varepsilon$ のときの抵抗力を $\lambda\left(Q_{s i}+Q_{R B}\right)$ とし、 $\left|\dot{u}_{d d}\right|<\varepsilon$ のときの抵 抗力を $\left|\lambda\left(Q_{s i}+Q_{R B}\right)\right| \times\left(\dot{u}_{d d} / \varepsilon\right)$ とする。（すなわち、極めて剛塑性に近いバイリ ニア型の速度-荷重関係とする。) 前者の場合、 $\lambda\left(Q_{s i}+Q_{R B}\right)$ は軸速度 $\dot{u}_{d d}$ と同符 号である。このように扱うと $\lambda\left(Q_{s i}+Q_{R B}\right)$ は、軸速度の絶対值 $\left|\dot{u}_{d d}\right|$ に依存する係 数 $c_{f}$ と軸速度 $\dot{u}_{d d}$ の積で表せる。

付録 B 変位応答倍率最適調整条件における同調粘性マスダンパー諸元

定点理論に基づく変位応答倍率最適調整条件（最適同調振動数比 $\gamma_{o p t}$ と付

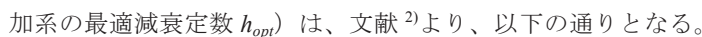

柔バネ解： $\gamma_{o p t}=\omega / \omega_{s}=(1-\sqrt{1-4 \mu}) /(2 \mu) ， \quad h_{o p t}=\sqrt{3(1-\sqrt{1-4 \mu})} / 4 \quad \ldots(\mathrm{B} 1)$ $\int \mu=m_{i 1} / M_{s}$ : 質量比, $m_{i 1}$ : 同調粘性マスダンパー（付加系）の等価質量

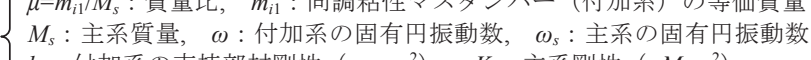
$k_{b}$ : 付加系の支持部材剛性 $\left(=m_{i 1} \omega^{2}\right), K_{s}$ : 主系剛性 $\left(=M_{s} \omega_{s}^{2}\right)$

同調粘性マスダンパー (付加系) の変位応答倍率最適調整条件（柔バネ解） における支持部材剛性 $k_{b}$ と粘性減衰係数 $c_{d}$ は、以下の通りとなる。

$$
\begin{aligned}
& k_{b}=\omega^{2} \cdot m_{i 1}=\left(\gamma_{o p t} \cdot \omega_{s}\right)^{2} m_{i 1}=\mu \cdot \gamma_{o p t}{ }^{2} \times K_{s} \\
& c_{d}=2 h_{\text {opt }} \cdot \omega \cdot m_{i 1}=2 h_{\text {opt }}\left(\gamma_{\text {opt }} \cdot \omega_{s}\right) \cdot m_{i 1}=2 h_{\text {opt }} \cdot \gamma_{\text {opt }} \cdot \mu \times \omega_{s} M_{s}
\end{aligned}
$$

